\title{
Title: Long-term collapse in fruit availability threatens Central African forest megafauna ${ }^{\S}$
}

Authors: Emma R. Bush ${ }^{1,2} \uparrow$, Robin C. Whytock ${ }^{1,3^{*} \dagger}$, Laila Bahaa-el-din ${ }^{4}$, Stéphanie Bourgeois ${ }^{3}$, Nils Bunnefeld ${ }^{1}$, Anabelle W. Cardoso ${ }^{5,6}$, Jean Thoussaint Dikangadissi ${ }^{3}$, Pacôme Dimbonda ${ }^{3}$, Edmond Dimoto $^{3}$, Josué Edzang Ndong ${ }^{3}$, Kathryn J. Jeffery ${ }^{1}$, David Lehmann ${ }^{3}$, Loïc Makaga ${ }^{3}$, Brice Momboua $^{3}$, Ludovic R. W. Momont ${ }^{7}$, Caroline E. G. Tutin ${ }^{1}$, Lee J. T. White ${ }^{1,8,9}$, Alden Whittaker ${ }^{10}$, Katharine Abernethy ${ }^{1,9}$.

\section{Affiliations:}

${ }^{1}$ Faculty of Natural Sciences, University of Stirling, Stirling, UK

${ }^{2}$ Royal Botanic Garden Edinburgh, Edinburgh, UK

${ }^{3}$ Agence Nationale des Parcs Nationaux (ANPN), Libreville, Gabon

${ }^{4}$ School of Life Sciences, University of KwaZulu-Natal, South Africa

${ }^{5}$ Ecology and Evolutionary Biology Department, Osborne Memorial Labs, Yale University, Connecticut, USA

${ }^{6}$ Environmental Change Institute, School of Geography and the Environment, Oxford University,

15 Oxford, UK

${ }^{7}$ Independent researcher, Saint-Maur-des-Fossés, France

${ }^{8}$ Ministère des Eaux, des Forêts, de la Mer, de l'Environnement chargé du Plan Climat, des Objectifs de Development Durable et du Plan d'Affectation des Terres, Boulevard Triomphale, Libreville, Gabon

$20{ }^{9}$ Institut de Recherche en Ecologie Tropicale, CENAREST, Libreville, Gabon

${ }^{10}$ Independent researcher, Colorado, USA

*Correspondence to: emma.bush.ecology@gmail.com and robbie.whytock1@stir.ac.uk

$†$ Emma R. Bush and Robin C. Whytock made equal contributions to this manuscript.

\section{Abstract:}

Afrotropical forests host many of the world's remaining megafauna, but even here they are confined to areas where direct human influences are low. We use a rare long-term dataset of tree reproduction and a photographic database of forest elephants to assess food availability and body condition of an emblematic megafauna species at Lopé National Park, Gabon. We show an 81\% decline in fruiting over a 32-year period (1986-2018) and an 11\% decline in body condition of fruit-dependent forest elephants from 2008-2018. Fruit famine in one of the last strongholds for African forest elephants should raise concern for the ability of this species and other fruit-

\footnotetext{
$\S$ This manuscript has been accepted for publication in Science. This version has not undergone final editing. Please refer to the complete version of record at https://science.sciencemag.org/content/early/2020/09/23/science.abc 7791 . The manuscript may not be reproduced or used in any manner that does not fall within the fair use provisions of the Copyright Act without the prior, written permission of AAAS.
} 
dependent megafauna to persist in the long-term, with consequences for broader ecosystem and biosphere functioning.

\section{One sentence summary:}

5 Simultaneous declines in tree reproduction and forest elephant body condition in a forest reserve in Gabon. 


\section{Main Text:}

The largest plants and animals on the planet are disproportionately important for the metabolism and functioning of our ecosystems (1). However, they are also more susceptible to extinction (2), and "global downsizing" via loss of mega fauna and flora is likely to have negative consequences for the biosphere (1). The African tropics are home to many of the world's remaining wild megafauna, but even here they are mainly confined to areas where direct human influences are low $(3,4)$. Securing the future of these megafauna populations will depend not only on protection against human threats such as habitat loss and hunting for international trade $(5,6)$, but also on maintaining the health and productivity of the habitats that support them. The creeping influence of the Anthropocene means that rapid climate and atmospheric changes will be felt even where direct human pressures are low, with potential for far reaching impacts on habitats and species (7). Detecting, quantifying and understanding changes to the health and functioning of the remaining safe havens for threatened megafauna should be a key conservation priority during this time of rapid change. In this paper we use a rare long-term dataset of plant

15 reproduction and a photographic database of forest elephants to assess food availability and body condition of an emblematic species of megafauna within a Central African rainforest.

Fruit is a keystone resource for many of the African megafauna $(8-10)$. Fruit production is highly dependent on climatic cues and there is abundant evidence that climate change has already caused shifts in the timing of plant reproduction in temperate regions (11-13). Data on reproduction of tropical plants are generally scarce or have not been recorded for long enough to track such changes (14). However, tropical plants will be impacted by climate change and where rare long-term data are available, changes in tropical tree reproduction have been detected at several sites (15-17). The mechanistic causes of these changes are not universal and are mostly 
unknown. The critical minimum temperature hypothesis describes how some Afrotropical plant species require temperatures to drop below a certain threshold to trigger flowering (18). For these species we would expect reproduction to be cued less often as temperatures rise.

Lopé National Park, Gabon, is a nationally designated protected area and a UNESCO World Heritage site and is a relative safe haven for Central African megafauna, such as great apes and forest elephants $(3,4,19)$. It also hosts the longest continuous study of tropical tree phenology in Africa (20). Researchers at the site have monitored tree species important to the diet of gorillas, chimpanzees and elephants from 1986 to the present. Once a month, focal tree crowns are observed from the ground using binoculars and the proportions of each canopy covered with

10 flowers, fruit and leaves are recorded (21). We quantified changes in the probability of encountering flowers, unripe and ripe fruit for 73 species over a 32-year period (1986-2018; $\mathrm{n}=$ 260,431 monthly-crown observations, n=2007 focal tree crowns; Tables S1, S2) while accounting for individual and species-level variation using generalised linear mixed models (GLMM) with a binomial error structure (22). We replicated this analysis for a subset of species

15 ( $n=14$ species) bearing fruit previously identified as being especially important in the diet of forest elephants during a 30-month dung study and an eight-year observational study of elephant diet at the site (9). We also calculated a ripe fruit availability score for each year as a proportion of maximum theoretical fruit availability (equivalent to all trees of all species bearing 100\% canopy cover of ripe fruit for 12 months of the year) selecting species that had been monitored continuously throughout the study period ( $\mathrm{n}=40$ species), and separately for important elephant fruit species only ( $\mathrm{n}=7$ species).

We found that trees at Lopé are reproducing less often, and that the probability of encountering flowers and fruit has declined significantly over time (GLMM; Tables S3, S4 and Figure S1). 
The average rate of encountering ripe fruit for all species $(n=73)$ dropped from one in every 10 trees in any given month in 1987 to fewer than one in 50 by 2018 , a striking $80.9 \%$ decline (Figure 1A; Table S4). While there was some variation between species, all species declined except one (Dacryodes buettneri; Table S5 and Figure S2). Ripe fruit encounters for important elephant fruit species $(\mathrm{n}=14)$ declined at an even faster rate $(-87.8 \%)$, from one in five trees in 1987 to fewer than one in 40 in 2018 (Figure 1A). A general reduction in fruit availability for species monitored throughout the time period demonstrates that the diminished frequency of fruit encounter has not been compensated for by larger fruiting events (Figure 1B). Availability of important elephant fruit dropped steeply between 2000 and 2003, with the best fruit production

10 years post-2004 lower than the poor years pre-2000 (Figure 1B). While the long dry season (June - September) has always been a time of fruit scarcity (10), historical seasonality in fruit availability has disappeared in recent years with a major reduction in ripe fruit observed from October to March, which was previously the season of abundance (Figure 1C).

Our results showing declines in the probability of encountering flowers and unripe fruit (Figure

$15 \mathrm{~S} 1)$ indicate that suppressed ripe fruit production is not primarily a pollination or fruit maturation issue. Nor is it likely to be due to any negative consequences of tree senescence, because we removed trees that died or were diseased prior to analysis, and found no evidence that tree size (as a proxy for tree age) influenced reproduction over time (Figure S3). Instead we consider it likely that climate changes experienced at the site have contributed to this shift in reproduction. 20 Global warming has caused minimum daily temperature to increase on average by $0.25^{\circ} \mathrm{C}$ per decade at Lopé (23), which may be a key factor in reduced reproduction for some tree species that rely on a critical minimum temperature to trigger flowering (18). Rainfall has 
simultaneously decreased at the site by $75 \mathrm{~mm}$ per decade (23); thus, all tree species might be suffering water stress (24).

Given the decline in fruit since 1986, it is likely that fruit-dependent wildlife such as forest elephants, great apes, monkeys and many bird species have been affected. Long-term population data are not available for these species at Lopé. Other measures of population health, such as body condition, can be used to measure population responses to environmental change over relatively short periods. Forest elephants, the largest frugivore in the ecosystem (9), have been consistently photographed by researchers and visitors to the site since the late 1990 s, resulting in a large photographic database ( $>80,000$ photos). We used this database to evaluate annual and seasonal trends in the external body condition of forest elephants between 1997 and 2018 , hypothesising that elephant body condition has declined alongside reduced food availability. Elephant body condition in photos was scored systematically using a custom-built webapplication and user interface (22). Scorers $(n=6)$ were blinded from the time and date of photographs and from the research question and hypothesis. Scoring effort ( $n$ photos viewed per

15 scorer) varied but we found high agreement between scorers using a standardised test database (mean intraclass correlation coefficient of $0.89, n=200$ photos). A total of 2823 photos met the strict image-quality criteria for scoring and we used linear mixed effects models (LMMs) to quantify changes in elephant body condition (accounting for elephant age) over the full 21-year period, and separately for the first 11 years (1997 to 2007) and last 11 years (2008 to 2018) of 20 data.

We detected long-term declines in forest elephant body condition at Lopé (LMM). For the period between 1997 and 2018, mean body condition of the population declined by $5.0 \%$ for all age classes. However, uncertainty was high, ranging from a small improvement in body condition to 
a large decline (LMM; 95\% confidence intervals $=+0.9 \%,-11.2 \%$; Table S6). The change was most marked in the second half of the time period (2008 - 2018) when body condition declined on average by $11.1 \%(\mathrm{LMM} ; 95 \%$ confidence intervals $=-4.3 \%,-15.6 \%$; Figure $2 \mathrm{~A}$, Table S6). Body condition varied seasonally in the first half of the time period (1997 - 2007) appearing to track fruit availability (dipping in June and peaking after the long dry season) without any obvious lag at the monthly resolution of this analysis (Figure 1B). The sharp drop in body condition in November during 1997 - 2007 was inconsistent with fruit availability, but closer inspection of the data indicated that this was highly influenced by one very thin individual recorded in November 1999 (body condition score =2) out of only three photos available for this 10 calendar month during this period (Table S7). In the 2008 - 2018 period the peak in body condition following the long dry season had disappeared (Figure 2B, Table S6). However, the sparse data for 1997-2007 and high uncertainty in the confidence intervals for seasonality in body condition means that comparisons between the early and late time periods should be made with caution (Tables S6 and S7).

15 It is unknown if the changes observed in body condition in this study have affected forest elephant population health or dynamics in the study area. However, studies of African savanna elephants show that environmental stressors can have dramatic long-term consequences for both individual fitness and population dynamics, with reproductive females and calves particularly affected (25). Reduced food availability could also act in synergy with other factors such as disease to magnify negative physiological consequences (Table S8). Although the biological mechanisms and consequences of declining body condition are unclear at this point, the effects on forest elephant populations across the region are unlikely to be benign, particularly when coupled with illegal hunting, habitat loss and habitat degradation (3). 
The declines described here in both plant reproduction and elephant body condition are indicative of system-wide change, and are expected to have disproportionate impacts on the functioning and metabolism of the ecosystem. A reduction or displacement of historic populations of large frugivores in this region, alongside reduced availability of seeds, could lead to collapse of seed dispersal (8), landscape-level shifts in habitat structure (26), reduction of carbon stocks (27) and potential for increased competition with humans for food (28). However, long-lived plant and animal species are able to buffer environmental change to a certain extent (1) and the broad diet of forest elephants (9) means that alternative food sources could offer some relief. Nonetheless, environmental stress can have life-long negative impacts on elephant survival and fitness (25) and the impacts of these changes should be closely monitored.

The long-term plant and animal datasets presented here are rare in the tropics and it's possible that such changes may be occurring elsewhere undocumented. These data are a reminder that even where direct human pressures are low, plant and animal communities may not be protected from the creeping influences of the Anthropocene. Coordinated international efforts to relieve

15 direct human pressures and to halt and reverse climate change will be critical to saving the remaining megafauna and flora of the African tropics and their unique role in the functioning of our biosphere. 


\section{References and notes:}

1. B. J. Enquist, A. J. Abraham, M. B. J. Harfoot, Y. Malhi, C. E. Doughty, The megabiota are disproportionately important for biosphere functioning. Nat. Commun. 11, 1-11 (2020).

2. R. Dirzo, H. S. Young, M. Galetti, G. Ceballos, N. J. B. Isaac, B. Collen, Defaunation in the Anthropocene. Science 345, 401-406 (2014).

3. F. Maisels, S. Strindberg, S. Blake, G. Wittemyer, J. Hart, Devastating Decline of Forest Elephants in Central Africa. PLoS One 8, 59469 (2013).

4. S. Strindberg, et al., Guns, germs, and trees determine density and distribution of gorillas and chimpanzees in Western Equatorial Africa. Sci. Adv. 4, eaar2964 (2018).

5. W. J. Ripple, et al., Bushmeat hunting and extinction risk to the world's mammals. R. Soc. Open Sci. 3 (2016), doi:10.1098/rsos.160498.

6. A. Benítez-López, et al., The impact of hunting on tropical mammal and bird populations. Science. 356, 180-183 (2017).

15 7. J. Barlow, et al., The future of hyperdiverse tropical ecosystems. Nature 559, 517-526 (2018).

8. A. Campos-Arceiz, S. Blake, Megagardeners of the forest - the role of elephants in seed dispersal. Acta Oecologica 37, 542-553 (2011).

9. L. J. T. White, thesis, University of Edinburgh (1992).

20 10. C. E. G. Tutin, L. J. T. White, "Primates, phenology and frugivory: Present, past and future patterns in the Lope Reserve, Gabon.” in Dynamics of Tropical Communities: 37th 
Symposium of the British Ecological Society, D. M. Newbery, H. H. T. Prins, N. Brown, Eds. (Blackwell Science, Oxford, 1998), pp. 309-338.

11. G. Waltheret al., Ecological responses to recent climate change. Nature 416, 389-395 (2002).

12. C. Parmesan, G. Yohe, A globally coherent fingerprint of climate change impacts across natural systems. Nature 421, 37 (2003).

13. C. Rosenzweig, et al., "Assessment of observed changes and responses in natural and managed systems" in Climate Change 2007: Impacts, Adaptation and Vulnerability. Contribution of Working Group II to the Fourth Assessment Report of the Intergovernmental Panel on Climate Change, M. L. Parry, O. F. Canziani, J. P. Palutikof, P. J. van der Linden, C. E. Hanson, Eds. (Cambridge University Press, Cambridge, 2007), pp. 79-131.

14. K. Abernethy, E. R. Bush, P. M. Forget, I. Mendoza, L. P. C. Morellato, Current issues in tropical phenology: a synthesis. Biotropica 50 (2018), pp. 477-482.

15 15. C. A. Chapman, K. Valenta, T. R. Bonnel, K. A. Brown, L. J. Chapman, Solar radiation and ENSO predict fruiting phenology patterns in a 15-year record from Kibale National Park, Uganda. Biotropica 50, 384-395 (2018).

16. S. Pau, D. K. Okamoto, O. Calderón, S. J. Wright, Long-term increases in tropical flowering activity across growth forms in response to rising $\mathrm{CO} 2$ and climate change. Glob. Chang. Biol. 24, 2105-2116 (2017).

17. L. Polansky, C. Boesch, Long-term Changes in Fruit Phenology in a West African Lowland Tropical Rain Forest are Not Explained by Rainfall. Biotropica 45, 434-440 
(2013).

18. C. E. G. Tutin, M. Fernandez, Relationships between minimum temperature and fruit production in some tropical forest trees in Gabon. J. Trop. Ecol. 9, 241-248 (1993).

19. P. D. Walsh, et al., Catastrophic ape decline in western equatorial Africa. Nature 422, 611-614 (2003).

20. G. S. Adamescu, et al., Annual cycles are the most common reproductive strategy in African tropical tree communities. Biotropica 50, 418-430 (2018).

21. E. R. Bush, et al., Towards effective monitoring of tropical phenology: Maximising returns and reducing uncertainty in long-term studies. Biotropica 50, 455-464 (2018).

10 22. See Supplementary Material.

23. E. R. Bush, et al., Rare ground data confirm significant warming and drying in western equatorial Africa. PeerJ 8, e8732 (2020).

24. T. J. Brodribb, J. Powers, H. Cochard, B. Choat, Hanging by a thread? Forests and drought. Science 368, 261-266 (2020).

15 25. P. C. Lee, L. F. Bussière, C. E. Webber, J. H. Poole, C. J. Moss, Enduring consequences of early experiences: 40 year effects on survival and success among African elephants (Loxodonta africana ). Biol. Lett. 9, 20130011 (2013).

26. A. W. Cardoso, et al., The Role of Forest Elephants in Shaping Tropical Forest-Savanna Coexistence. Ecosystems 23 602-616 (2020).

20 27. F. Berzaghi, et al., Carbon stocks in central African forests enhanced by elephant disturbance. Nat. Geosci. 12, 725-729 (2019). 
28. S. Ngama, et al., Do topography and fruit presence influence occurrence and intensity of crop-raiding by forest elephants (Loxodonta africana cyclotis)? PLoS One 14 e0213971 (2019). 
Acknowledgments: We acknowledge Anna Deasey, Arthur Dibambou, Severin Obiang, Nigel Orbell, Ailsa White, Iona White, William White, Stephanie Schuttler and Fiona Maisels for their contributions to data collection and Fiona Maisels, Daisy Dent, Luc Bussiere and three anonymous reviewers for their comments which improved the final manuscript; Funding: During analysis and writing, EB was funded by The University of Stirling Impact Studentship and the Gabonese National Park Agency (Total Climate Change award and an Impact studentship); KA was funded by University of Stirling, RW was funded by the EU $11^{\text {eme }} \mathrm{FED}$ ECOFAC6 programme in Gabon; NB was funded by the European Research Council under the European Union's H2020/ERC grant agreement no. 679651 (ConFooBio). During their respective data collections, $\mathrm{LW}, \mathrm{KJ}, \mathrm{LRM}$ and $\mathrm{AW}$ were funded by the Wildlife Conservation Society; LW, RW, KJ, ED, JTD, PD, BM, LM \& DL were funded by the Gabon National Parks Agency; KA, DL and KJ were funded by the University of Stirling. ED, JTD, CT, KA \& KJ were funded by CIRMF, LB was funded by Panthera and AWC was funded by the University of Oxford's Hertford College Mortimer-May scholarship; Author contributions:

15 Conceptualization of the phenology and elephant monitoring research: LJTW, CEGT; Conceptualization of this analysis: EB, RW, LJTW, KA; Data curation: EB, RW, KJJ, DL, JEN, LRWM, KA, CT, LM; Formal analysis: EB, RW, NB; Funding acquisition: LJTW, KA, CEGT, KJJ; Investigation: EB, RW, LB, SB, AWC, JTD, PD, ED, JEN, KJJ, DL, LRWM, BM, LM, CT, LJTW, AW, KA; Methodology: EB, RW, NB, CT, LW, KA, SB; Project administration: EB, RW, KJ, KA, LJTW; Resources: RW, LB, AC, LRWM, AW; Software: EB, RW; Visualisation: $\mathrm{EB}, \mathrm{RW}$; Writing - original draft: $\mathrm{EB}, \mathrm{RW}, \mathrm{KA}$; Writing - review and editing: EB, RW, LB, SB, NB, AWC, JTD, PD, ED, JEN, KJJ, DL, LM, BM, LRWM, CET, LJTW, AW, KA; Competing interests: Lee White is Minister of Water, Forests, Seas, Environment and Climate Change for the Gabonese Republic; The Agence Nationale des Parcs Nationaux (ANPN), is an agency of the Gabonese government; and Data and materials availability: All data are available from the University of Stirling's online data repository (http://hdl.handle.net/11667/159). All code is available at https://zenodo.org/record/4022665. 


\section{Figure Legends}

Fig. 1. Changes in ripe fruit encounter and availability from 1986 to 2018 at Lopé National Park, Gabon. A. Results from a binomial generalised linear mixed effects model (Table S4) showing the change in probability of encountering ripe fruit over time for any given tree in any given month (solid lines) and 95\% confidence intervals (dashed lines). Summed raw data are plotted in

Figure S1. B. Interannual changes in ripe fruit availability for all species monitored consistently throughout the time period. Fruit availability is calculated as a proportion of maximum theoretical fruit availability; ripe fruit availability equals one when all trees in a subset have $100 \%$ canopy cover of ripe fruit for 12 months in a year. C. Results from a binomial generalised linear mixed effects model (Table S4) showing the seasonal change in probability of encountering ripe fruit for any given tree in each calendar month contrasted for the years 1987 and 2017 (points and solid lines) and accompanying 95\% confidence intervals (dashed vertical lines).

Fig. 2. Long-term and seasonal changes in elephant body condition from 1997 to 2018 at Lopé National Park, Gabon. (A) Change in elephant body condition from 2008 to 2018. Mean change (solid line) and 95\% confidence intervals (dashed lines) are from a linear mixed effect model (Table S6). (B) Mean monthly elephant body condition and 95\% confidence intervals from linear mixed effects models (Table S6) for the periods 1997 to 2007 (no data for January and December) and 2008 to 2018. Enlarged example images of elephant body condition scores are shown in Figure S4. 
Figure 1.
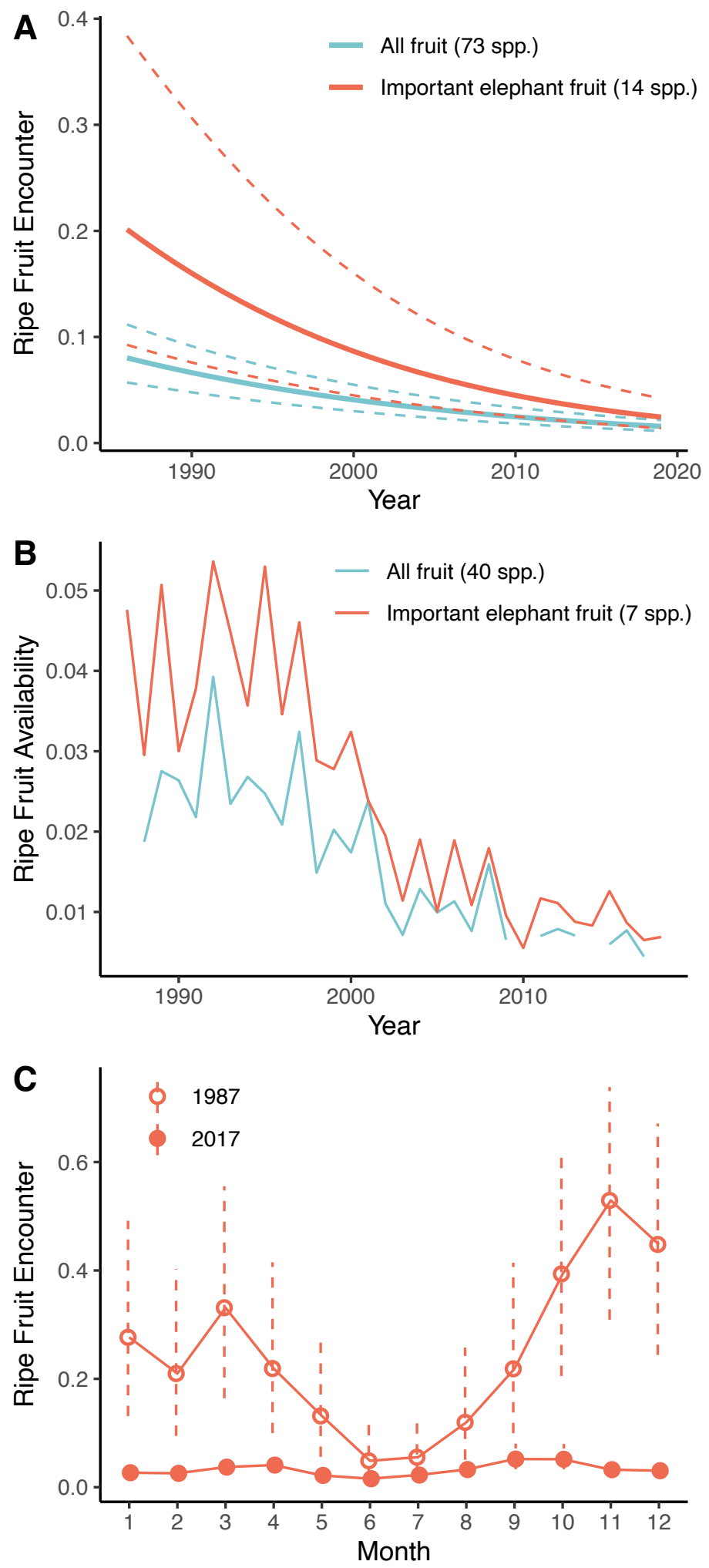
Figure 2.
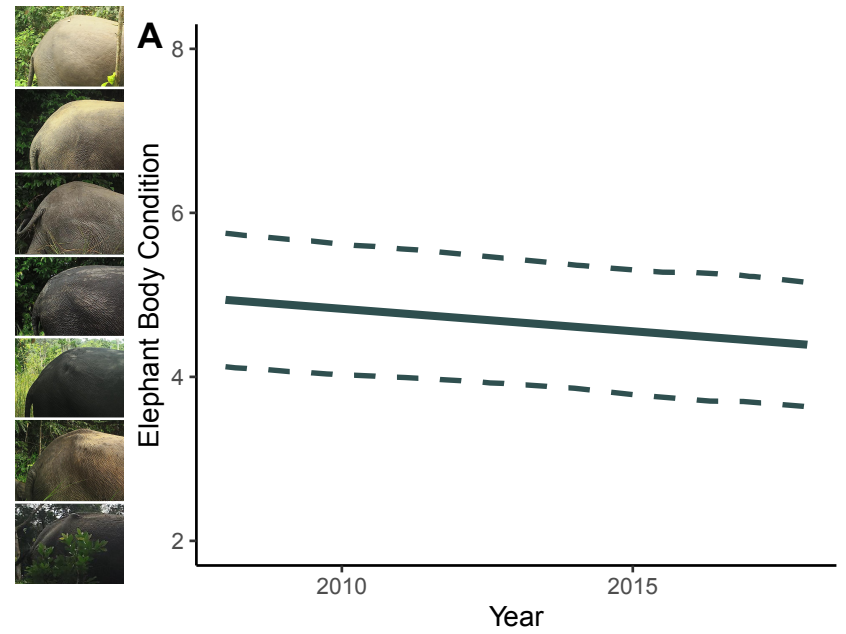

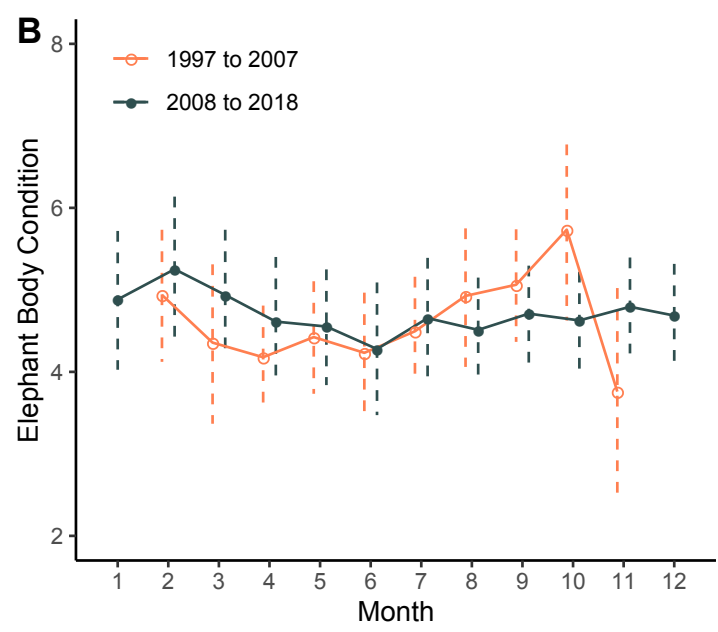

\section{List of Supplementary Materials:}

Materials and Methods

Figures S1-S7

Tables S1-S14

References (30-54) 


\section{Supplementary Materials for}

Long-term collapse in fruit availability threatens Central African forest megafauna

Emma R. Bush, Robin C. Whytock, Laila Bahaa-el-din, Stéphanie Bourgeois, Nils Bunnefeld, Anabelle W. Cardoso, Jean Thoussaint Dikangadissi, Pacôme Dimbonda, Edmond Dimoto, Josué Edzang Ndong, Kathryn J. Jeffery, David Lehmann, Loïc Makaga, Brice Momboua, Ludovic R. W. Momont, Caroline E. G. Tutin, Lee J. T. White, Alden Whittaker, Katharine Abernethy

15

correspondence to: emma.bush.ecology@gmail.com and robbie.whytock1@stir.ac.uk

\section{This PDF file includes:}

Materials and Methods

Figs. S1 to S7

Tables S1 to S14

Other Supplementary Materials for this manuscript includes the following:

25

Data availability: http://hdl.handle.net/11667/159

Code availability: https://zenodo.org/record/4022665 


\section{Materials and Methods}

\section{Data collection}

Fruit monitoring

Researchers at Lopé NP have monitored leafing and reproduction for tree species important to the diet of large frugivores at the site (gorillas, chimpanzees, elephants etc.) continuously since 1986. Focal tree crowns are observed each month using binoculars from the ground and 10 canopy coverage (0-100\%) of flowers and fruit is recorded (21). From the original dataset we removed any species for which fewer than three individuals were monitored and any trees that showed consistent signs of disease (noted in monthly comments by field scientists) or that died during the time period. The resulting sample included 260,431 monthly-crown observations of 2007 focal tree crowns ( 73 species, 27 families). Individual trees have been monitored for

15 between 1 and 395 months (mean = 139 months; Tables S1, S2 and Figure S5). 37 of the 73 species used in this study are known to be consumed by elephants and 14 of these species were previously identified as especially important in elephant diet as they were found in $>5 \%$ dung piles or for $>6$ months in a 30-month study of elephant dung at the site from Jan 1989 - July $1991(9)$.

20 Phenology data at Lopé are recorded by lead observers after at least one years' training in the field under another lead observer. Over the monitoring period of 395 months there have been fewer than 12 lead observers who have made continuous contributions of between 2 and 20 years. Lead observers who no longer continuously record data make regular repeat visits to the site, accompanying current lead observers and overseeing consistent methods. The current senior botanist at the site (author ED) has overseen phenology monitoring for 25 years and has trained all junior research assistants. While there may be some inter-observer biases in our data, the consistency between observers means that these should be minimal, especially since we use presence only data for the quantitative analyses in this study.

\section{Database of elephant photos}

We compiled several photographic databases of forest elephants taken between 1997 and 2018 across the study area. The methods used to take photos and their source varied during the study period (Table S9). We used all available photos except for two very large sources. In one source of photos (Cardoso, A; $n=80682$ photos) we selected a sub-sample of 547 photos during a pilot study. This was done first to reduce oversampling from this database and second to exclude photos already identified as inappropriate for scoring (see later). In a second source of photos (Bahaa-el-din, $\mathrm{L} ; n=2540$ photos), we also pre-screened the photos to exclude those that did not show the rear of the elephant to prevent oversampling and reduce effort during data collection. 
Various methods have been used to visually score the body condition of wild and captive African savanna elephants, Loxodonta africana, and Asian elephants, Elephas maximus (30-33), which are summarised in detail by Schiffman et al. (34). Here, we used the 'overview protocol' developed for female African elephants (33). This involves an observer visually assessing a photograph and assigning a score on a five-point scale by comparing the photograph to a reference set. Importantly, fat deposition rates of the body regions assessed using the overview method (ribs, pelvic bone, backbone) correlate with internal body fat deposition rates (35). The method was shown to give the most consistent body condition scores between multiple trained observers ( $n=18$ veterinary students, $n=15$ elephants) compared to two alternative approaches (composite or algorithm) (36). Here, we used a 10-point scale instead of the five-point scale used by Morfeld et al. (33), allowing us to capture greater variation in body condition, which was more suitable for regression analysis.

To standardise body condition scoring we created a customised web-app using the Shiny $\mathrm{R}$ package (37) (Figure S6). First, the app randomly presented a photograph from the database to the scorer. The scorer was then asked to identify the most central elephant in the photograph and rate the photo as 'good', 'moderate', 'poor' or 'discard' based on the general visibility and clarity of relevant body parts (abdomen, ribs, spine). Next, using a series of dropdown menus and sliders, scorers classified the viewing angle of the chosen individual (side, rear, rear-angle), sex (male, female, unknown), age (adult, immature, infant), if the elephant was obviously injured or sick (yes, no), the total number of individuals in the photo (sliding scale) and body condition (sliding scale). The body condition slider dynamically presented the scorer with the ten reference photos. These comprised the five given in Morfeld et al. (35) and a further five intermediate classes (identified from a pilot study). Scorers were presented with each photograph from the database only once.

None of the scorers had prior knowledge of the date, time or location of photos and this information was blinded to them during scoring to avoid bias. Photos were scored by a total of 13 scorers who varied in their knowledge of forest elephant biology and ecology. Scorer expertise ranged from a professional ecologist with no prior knowledge of forest elephants, research assistants working at Lopé National Park (with between two and five years professional experience), amateur naturalists who lived in Lopé National Park for $c .10$ years, active and retired scientists who worked or are working on tropical forest ecology in Gabon, and one Doctor in veterinary medicine, who also holds a PhD in forest elephant ecology and genetics (co-author SB). Scorer effort for non-discarded photos varied from five to 1671 photos and, because of the large database, single photos were rarely scored by all users. Therefore, to test agreement between scorers, we also asked them to score a standardised set of 200 photos (previously selected from the full database at random).

Scorers were excluded from the analysis if they had completed $<150$ photos from the main database (two research assistants and two professional ecologists), if they had not completed the standardised test set ( $n=1$, research assistant), if they had prior knowledge of the research

40 questions ( $n=1$, co-author RCW) and if their scores from the standardised test correlated weakly with other scorers ( $n=1$, scorer B in Figure S7). Finally, we removed the first 50 scores made by each of the scorers to allow for a 'burn-in' learning period. The remaining dataset therefore comprised results from six scorers (D, E, G, I, J, L in Figure S7). For this group, there was high repeatability in the standardised 200 photos with an intraclass correlation coefficient (mean ICC 45 for $k=6$ scorers) of $0.89(95 \%$ CI $0.87-0.91)$ using the ICC() function from the psych R package (38). Ten example images from the database are shown in Figure S4. 
$\underline{\text { Statistical analyses }}$

\section{Trends in rate of flower and fruit encounter over time}

We used generalised linear mixed effects models to quantify long-term trends in the probability of encountering flowers, unripe and ripe fruit over the observation period, $(260,431$ monthly focal tree crown observations of 2007 trees, 73 species). In each model we included the presence of flowers / unripe fruit / ripe fruit as the response variable and Year (mean-centred and scaled by one standard deviation) as a continuous fixed effect predictor. We included a random intercept for Month to deseasonalize the data, and random slopes for Year by Species ID and Tree ID to account for repeated measures and the hierarchical nature of the data (Table S10). We constructed null models without Year and used AIC to evaluate support. We re-ran the ripe fruit models for a smaller dataset including important elephant fruit species only (58319 monthly focal tree crown observations of 466 trees, 14 species) and again with this same smaller dataset including Month as a fixed effect predictor interacting with Year. Models were fitted using a binomial error distribution and maximum likelihood with the lme4 R package (39).

To investigate if tree age (and specifically senescence) had any effect on our results we calculated relative size (DBH of the tree / max recorded DBH of the species) as a proxy for tree age for each individual tree in our sample where size data were available (1171 trees measured between 1996 and 2015). We found no evidence of covariance when we plotted the random intercepts and slopes for these trees from the ripe fruit binomial model against relative size (Figure S3).

Ripe fruit availability

We also calculated a ripe fruit availability score for each year as a proportion of maximum theoretical fruit availability (equivalent to all trees of all species bearing $100 \%$ canopy cover of ripe fruit for 12 months of the year). For this score we chose a subset of 40 species that had been monitored continuously for the full study period (including seven of the important elephant fruit species; Figure S5). We calculated fruit availability per species for every month in the time series using the following formula: FAS (species, month) $=\mathrm{P} * \mathrm{C}$, where $\mathrm{P}=$ proportion of individuals with ripe fruit and $\mathrm{C}=$ the mean canopy coverage of ripe fruit for canopies where ripe fruit are present. We summed these scores for each month in the time series and divided by the number of species, and then summed per calendar year and divided by the number of months. In this way we created a time series of annual ripe fruit availability where a score of one represents full canopy coverage of ripe fruit for all species for 12 months of a year, and a score of zero represents no ripe fruit at all in that year.

\section{Trends in elephant body condition}

After removing photos unsuitable for scoring, the total number of unique photos scored was 2823 (Table S9) and the total number of scores was $5286(n=6$ scorers). Body condition data

45 from photos were highly structured with repeated photos of individual elephants or families often taken in short time series (Capture Events). Photos were also scored multiple times by different 
scorers. To identify unique Capture Events, we used a threshold of 10 minutes between consecutive photos. A visual inspection of results suggested this adequately separated independent sequences ( $n=905$ Capture Events, $n=2823$ photos between 1997 and 2018). Some photos were of known individuals, but this information was not consistently available across all years and was not used in the models.

Mixed-effects models can address issues such as pseudoreplication in time, but our repeated measure of unique photos nested within Capture Events was not repeated across the resolution of the time series used in the analysis (Year and Month). This is because multiple photos for any Capture Event only occurred in a single day. Since it was unclear how best to account for this unusual data structure, we used two modelling approaches (general linear models and linear mixed effects models). We then compared effect sizes and their direction from both approaches as a 'sanity check' before making inference. Our expectation was that if relationships and trends were strong, they would be relatively robust to different model structures.

We compared four alternative models of varying complexity to investigate temporal trends in Body Condition Score and relationships with elephant Age (Table S11). These models were repeated for the full 22 years of data (1997 to 2018, $n=5286$ scores, $n=2823$ photos, $n=905$ Capture Events), the first 11 years of data (1997 to 2007, $n=2401$ scores, $\mathrm{n}=1230$ photos, $\mathrm{n}=$ 148 Capture Events) and last 11 years of data (2008 to $2018, n=2885$ scores, $n=1593$ photos, $n=757$ Capture Events). Model relative goodness of fit was compared using corrected Akaike 20 Information Criterion $\left(\mathrm{AIC}_{\mathrm{c}}\right)$.

In the general linear model set, Body Condition Score was averaged across all scorers for each Capture Event as the response variable. In the linear mixed effects model set, we used the raw Body Condition Score for each image and scorer combination as the response variable. Age was included in the models as a three-level categorical predictor (Infant, Immature and Adult; using the most common Age class for each event in the GLMs). Year was included as a continuous fixed effect predictor, mean-centred and scaled by one standard deviation. Month was included as a 12-level categorical predictor. We did not include elephant Sex in the models because most photos (57.3\%) were classified as 'unknown' due to the angle of the photos and the absence of any obvious sexing criteria. In the linear mixed effects models, we accounted for pseudoreplication by including Capture Event and Scorer ID as random intercepts.

Generalised linear models were fitted with a Gaussian error distribution using base R (40) and mixed effects models were fitted using a Gaussian error distribution with the lme4 $\mathrm{R}$ package (39). We used maximum likelihood when comparing relative goodness of fit with $\mathrm{AIC}_{\mathrm{c}}$ and, for the linear mixed effects models we estimated parameters using restricted maximum likelihood. We used residual plots to visually assess model fit, identify potentially non-linear relationships and evaluate assumptions of homoscedasticity (41). 95\% confidence intervals were calculated using parametric bootstrapping $(\mathrm{n}=1000$ simulations). Results from the two modelling approaches were generally consistent (Tables S6, S12, S13, S14) and inference was made using the linear mixed effects models (Tables S6, S13). 

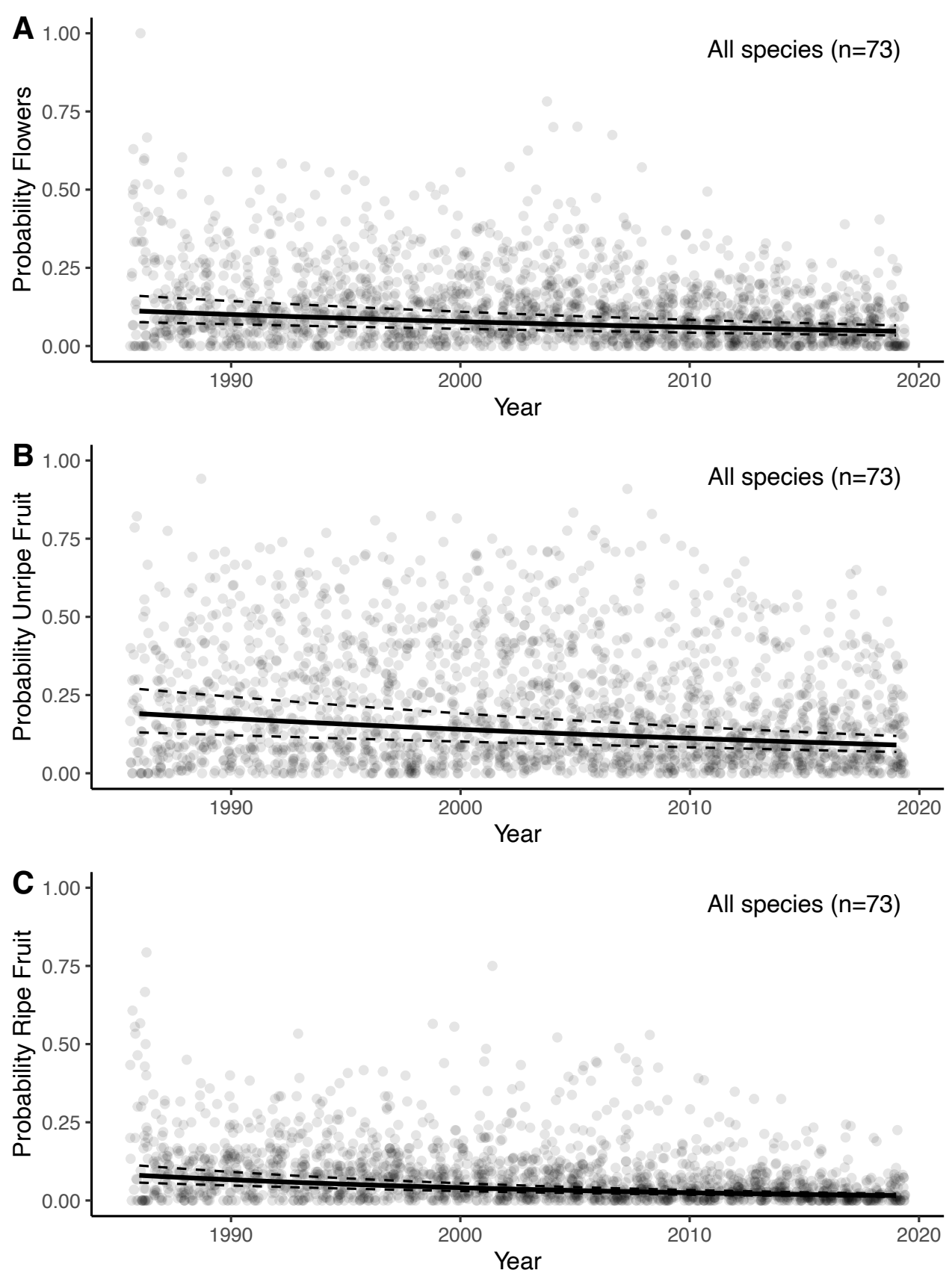

\section{Fig. S1.}

Changes in probability of encountering reproductive phenophases for all species $(n=73)$ monitored from 1986 to 2018 at Lopé National Park, Gabon. Predictions from a binomial generalised linear mixed model showing the change in probability of encountering (A) flowers, (B) Unripe fruit and (C) Ripe fruit over time for any given tree in any given month (solid lines) and $95 \%$ confidence intervals (dashed lines). Points indicate raw data summarised to mean probability of encountering that phenophase per species in that year. 


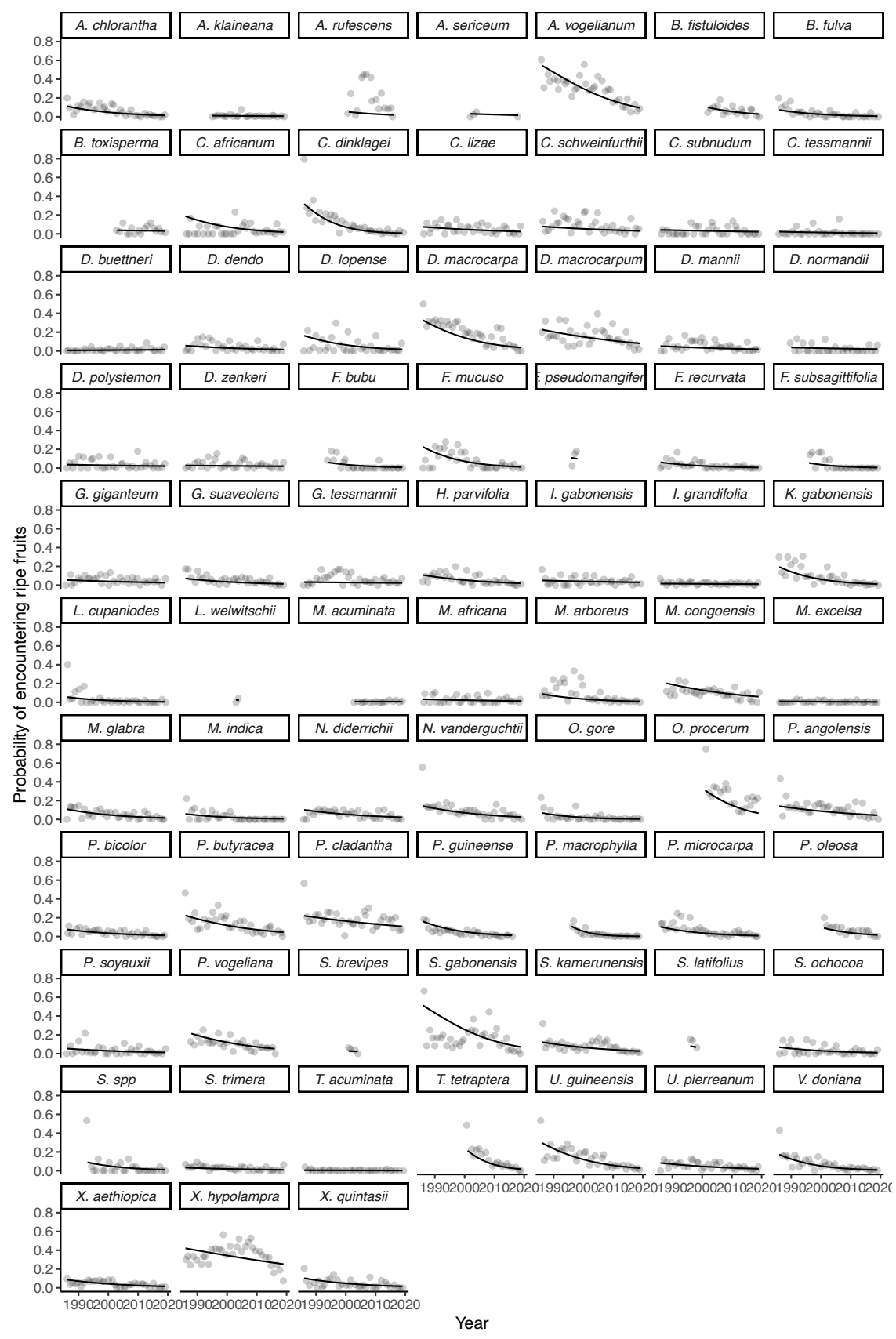

\section{Fig. S2.}

Species-level changes in probability of encountering ripe fruit for all species $(n=73)$ monitored from 1986 to 2018 at Lopé National Park, Gabon. Predictions are from a binomial generalised linear mixed model showing the change in probability of encountering ripe fruit (y axis) over time (x axis) for any given tree in any given month (solid lines) and raw data summarised to mean probability of encountering ripe fruit per species in that year (points). 

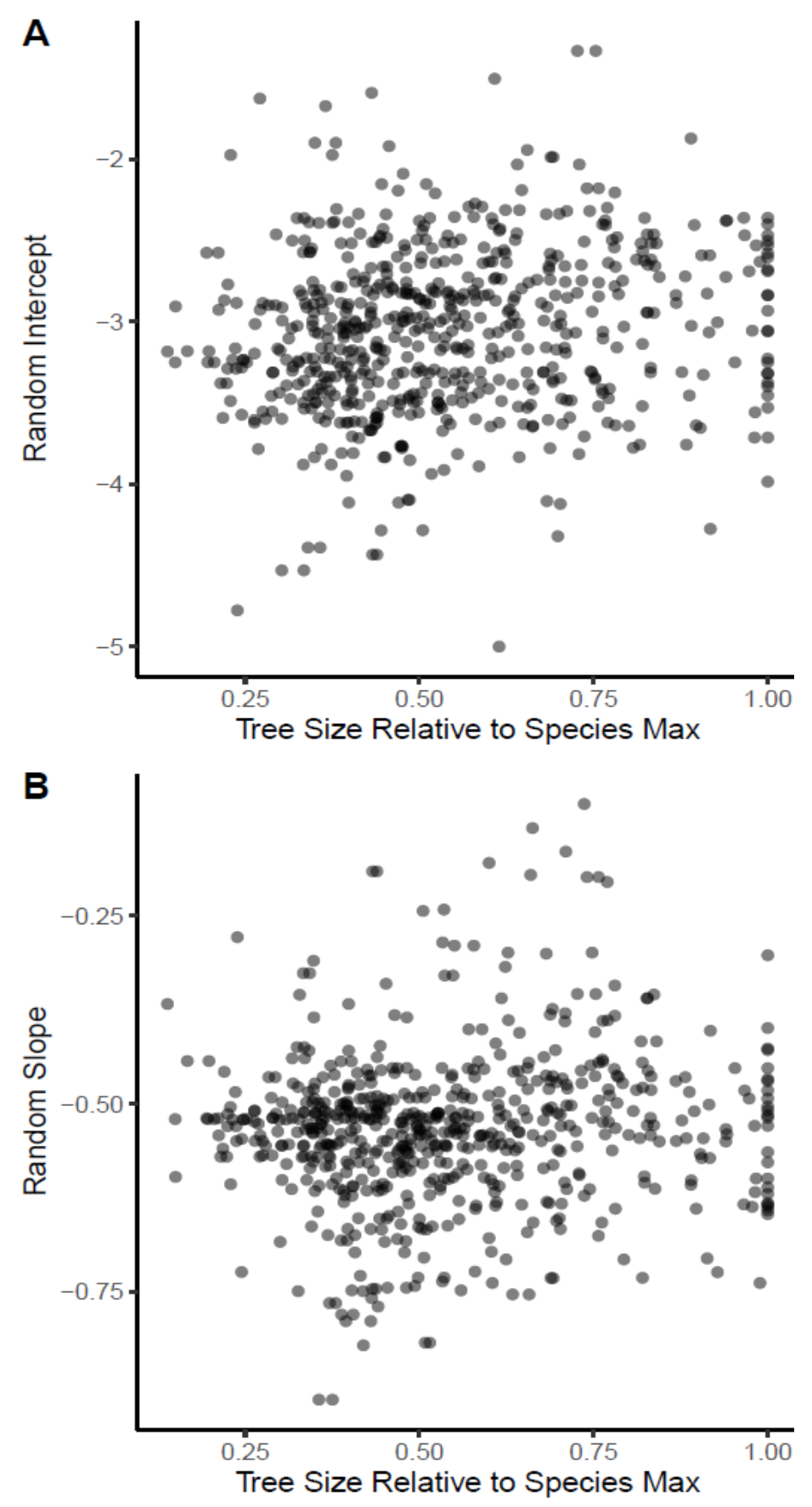

\section{Fig. S3.}

Comparison of random intercepts and random slopes over time for individual trees (derived from a generalized linear mixed effects model, Table S5) against their relative size as a proxy for age. Lack of covariance suggests that senescence is not an explanation for the observed decline in reproduction at our study site. 


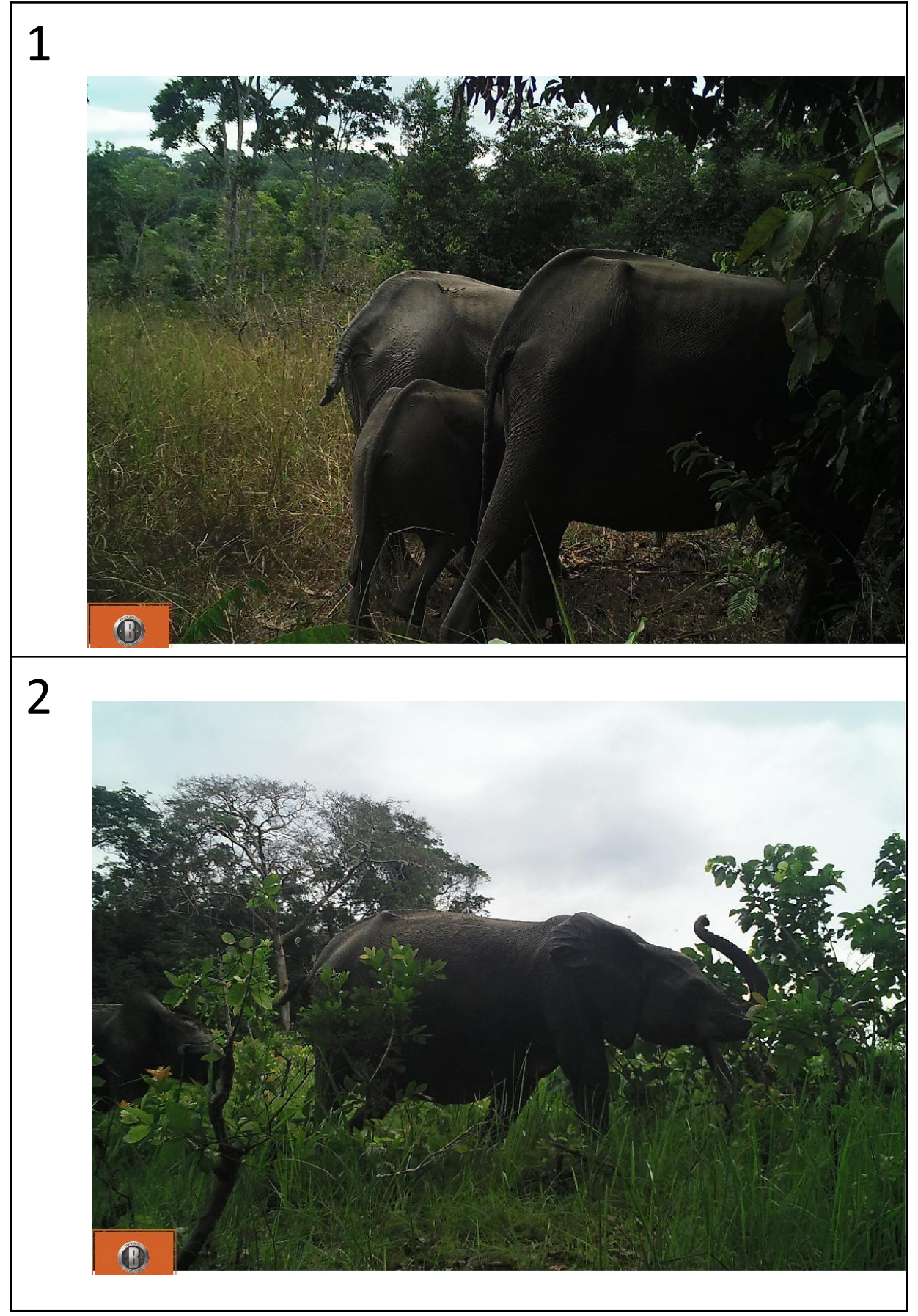

Fig. $S 4$ cont... 


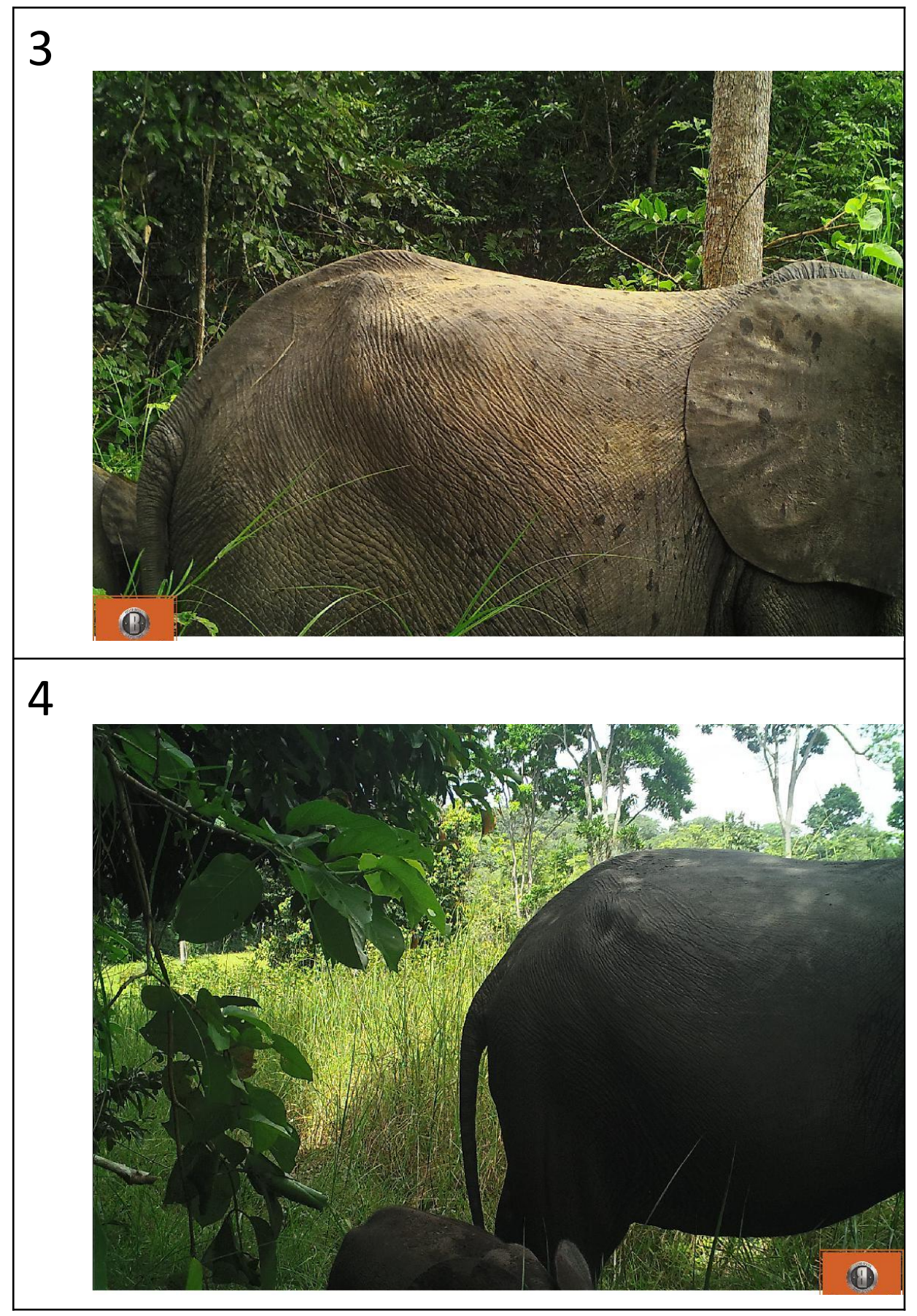

Fig. $\$ 4$ cont... 


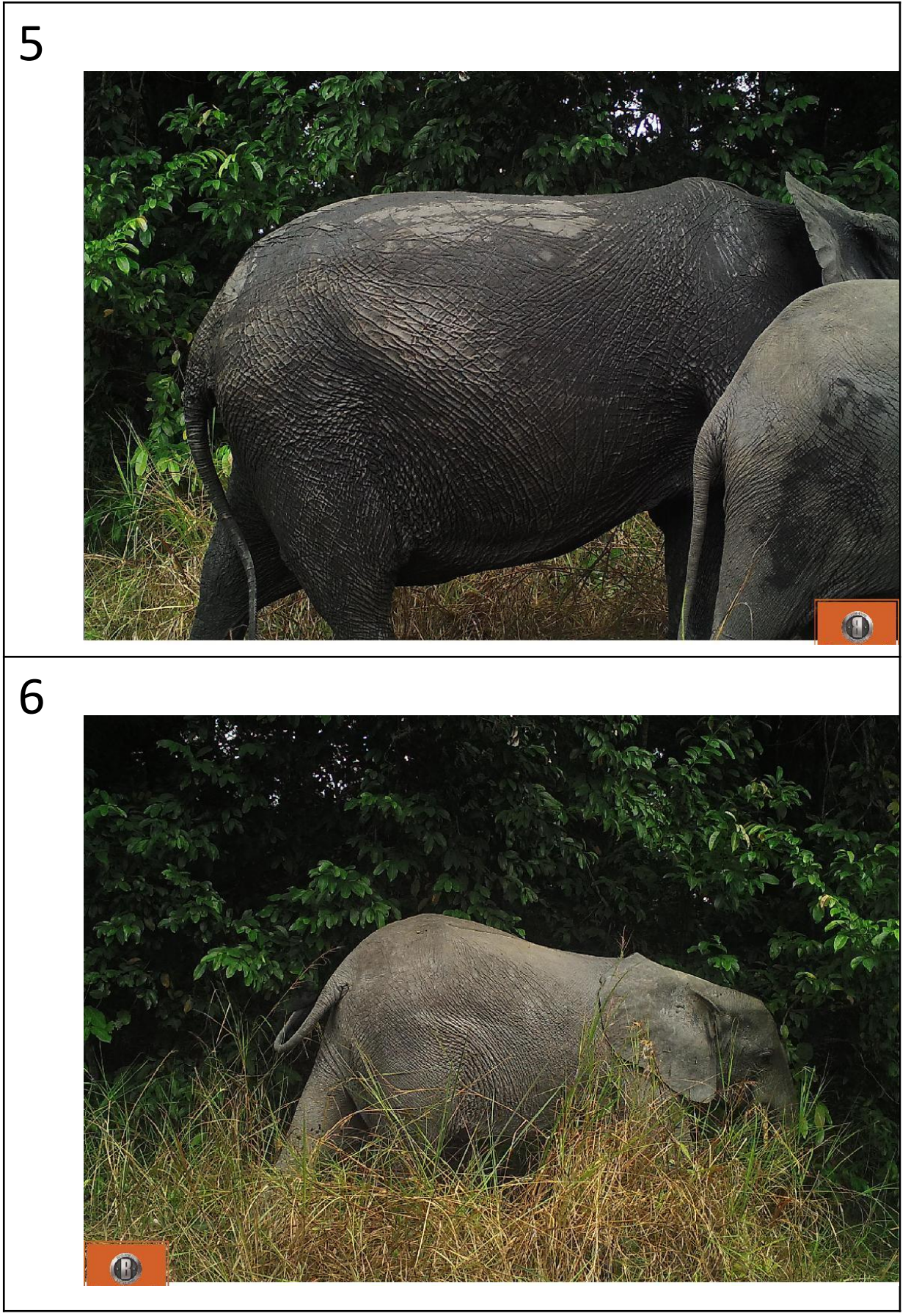

Fig. $S 4$ cont... 


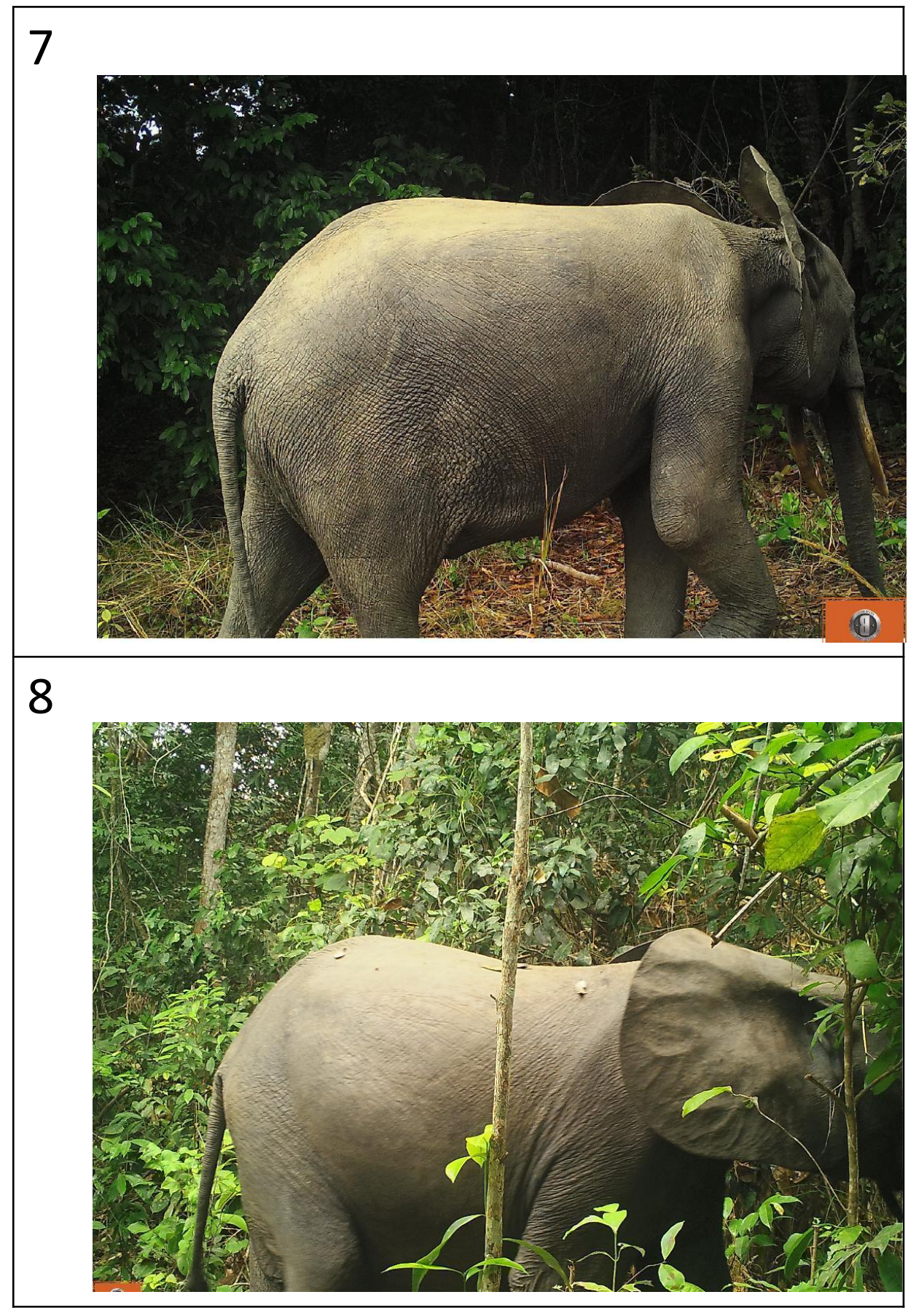

Fig. $\$ 4$ cont... 


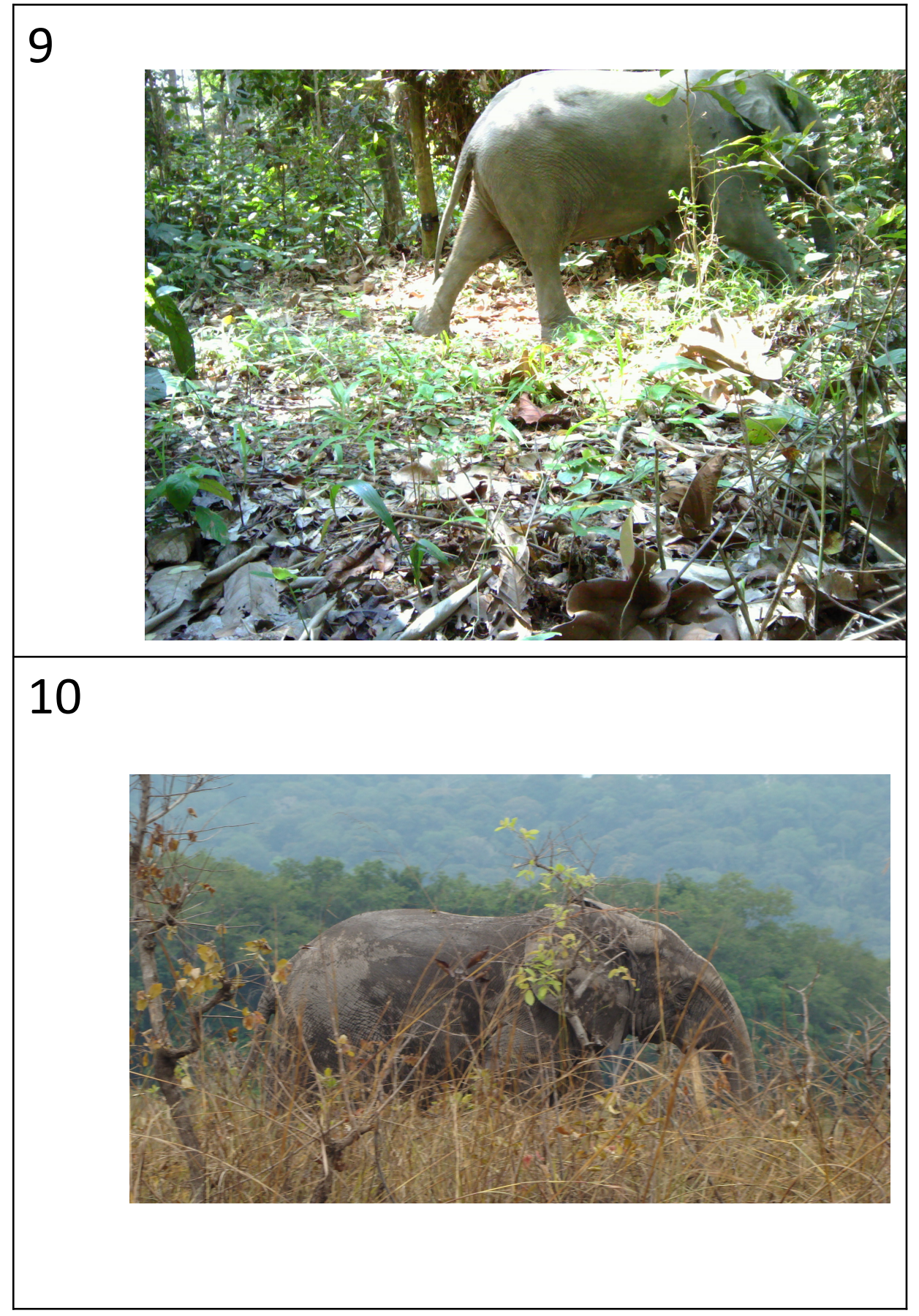

\section{Fig. S4.}

Examples from the photographic database of forest elephants at Lopé NP, Gabon to show the range of body condition scores from one to ten. Images were rotated so that the subject elephants face the same direction to allow easier comparison between these examples. 

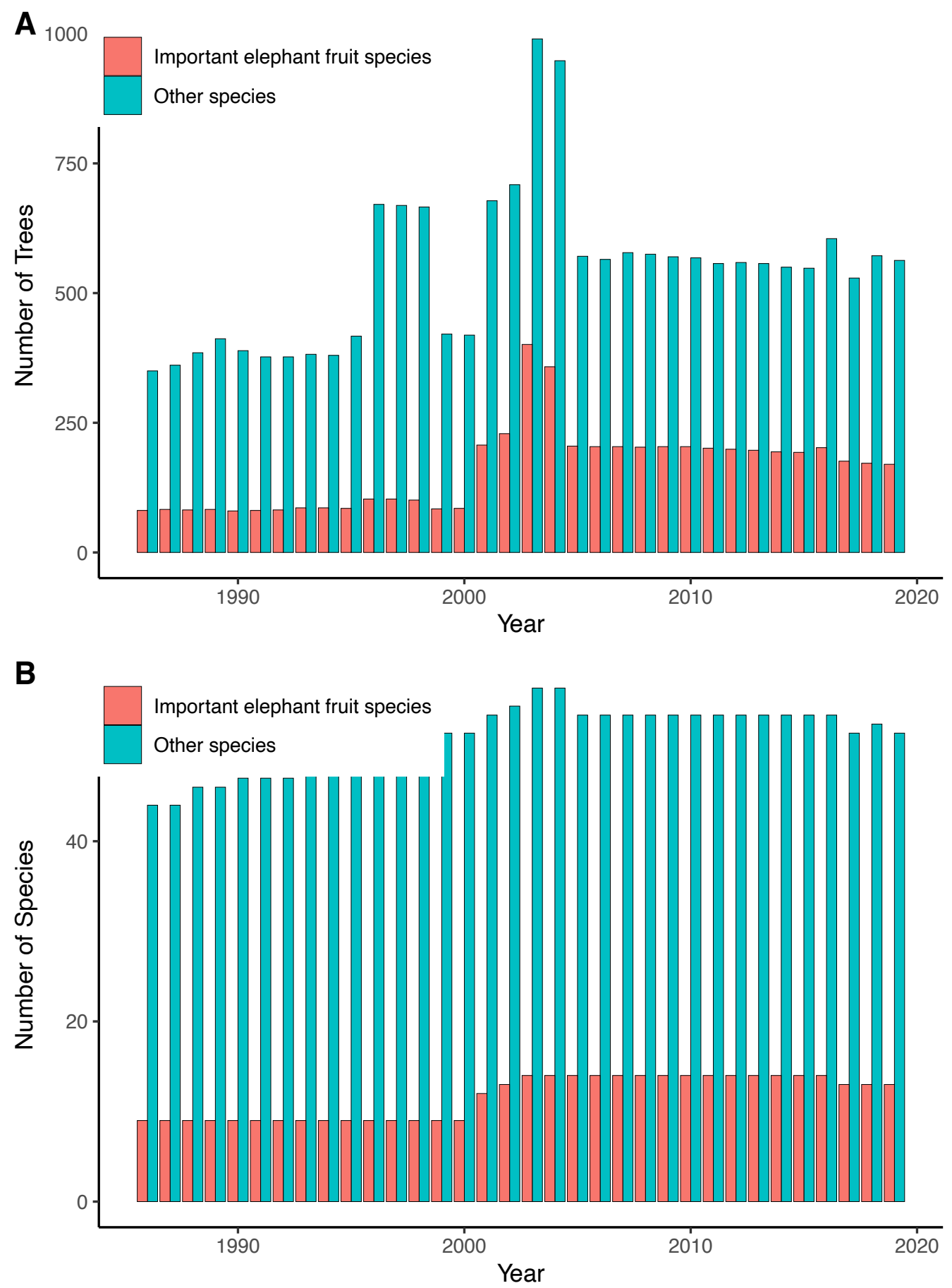

Fig. S5.

Visual summary of the sample of tree species monitored as part of the Lopé National Park longterm observational phenology study (1986-2018). Histograms show sampling effort within the 5 phenology dataset over time for (A) the total number of focal tree crowns and (B) the total number of species observed in each year of the study. 


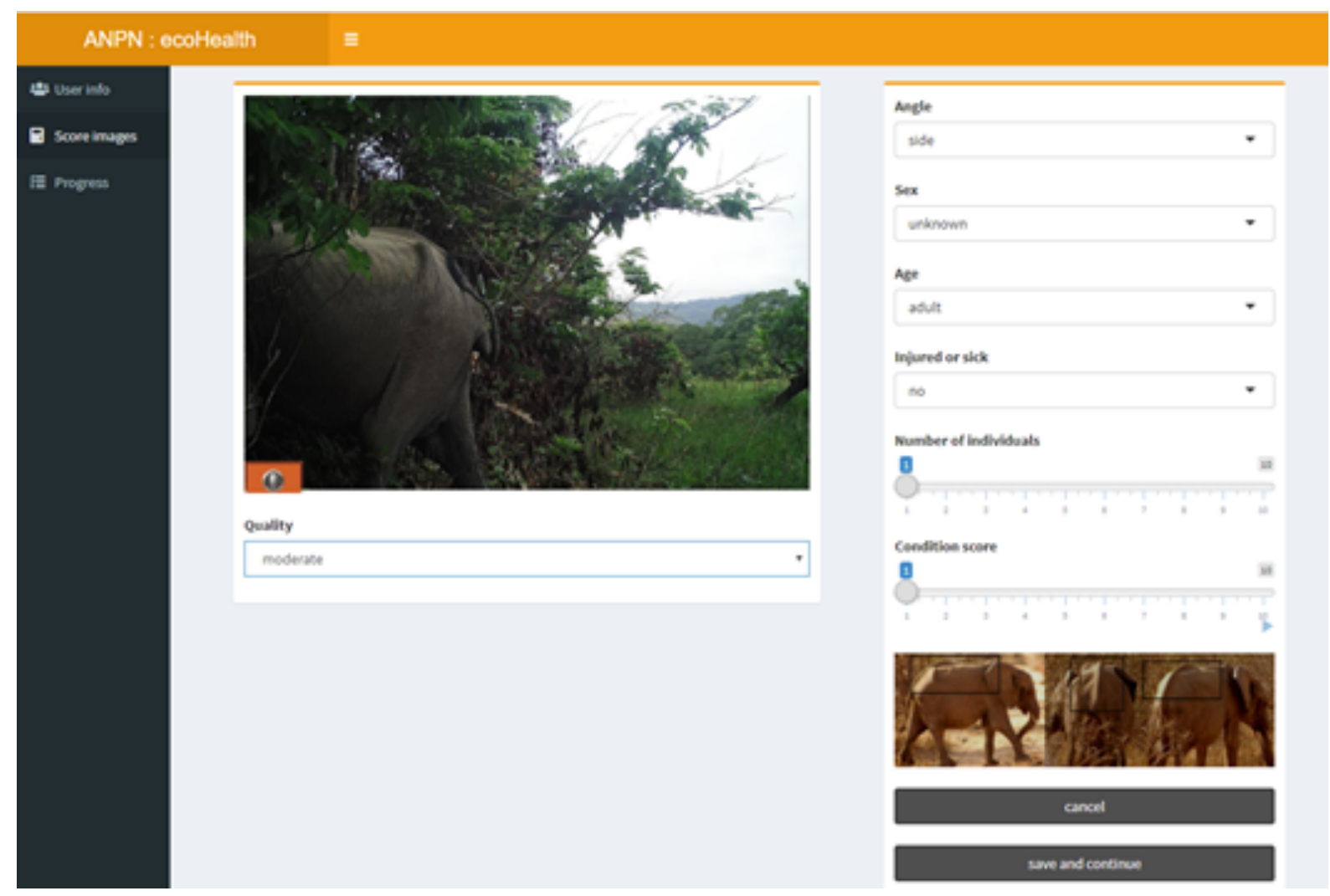

Fig. S6.

Screenshot of the shiny R web-app used to score body condition of forest elephants (a French language version was also used). 


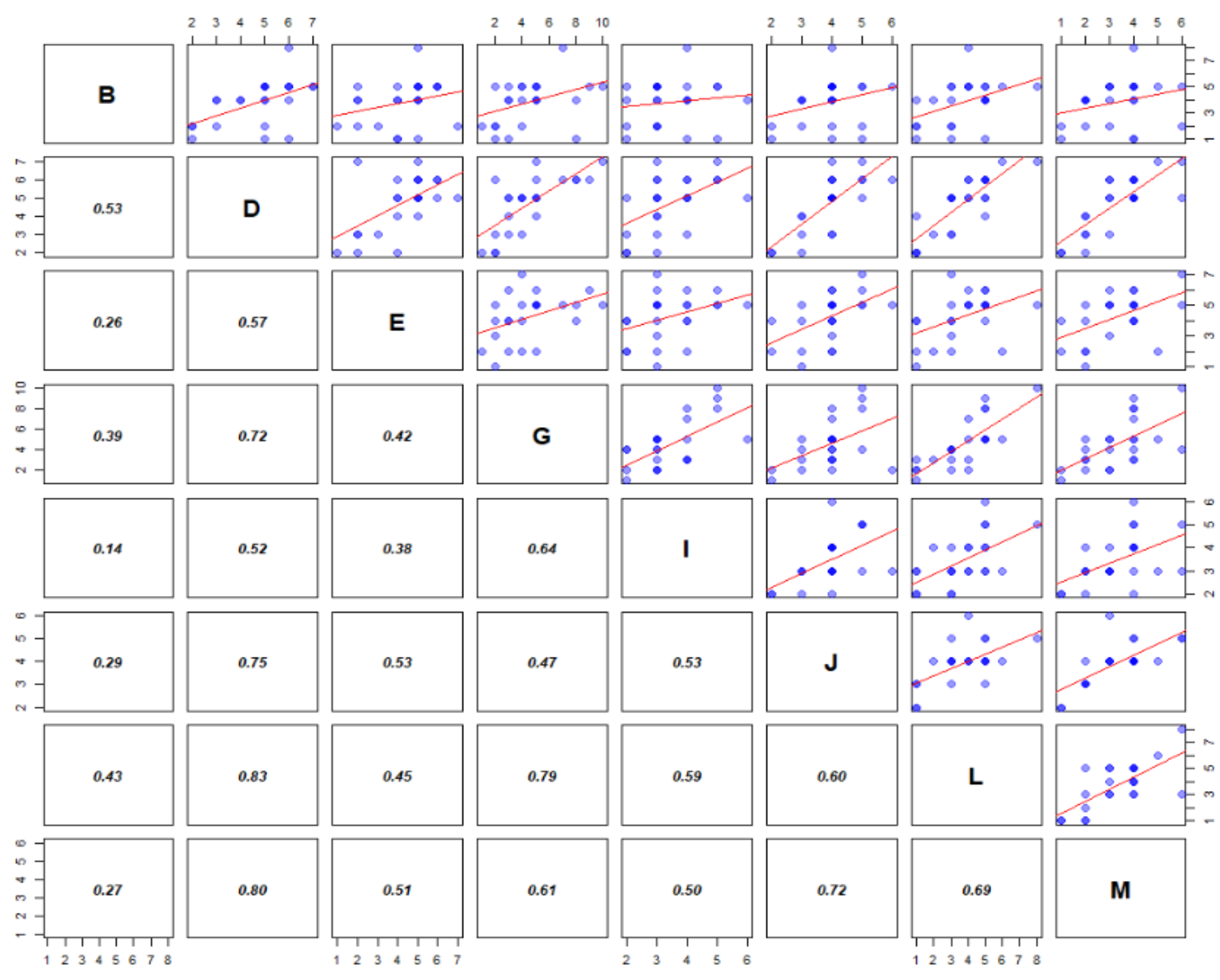

Fig. S7.

Pearson's correlations between eight of 13 scorers who completed the standardised database of 200 photos and who scored $>150$ images in the database. Photos designated as 'discard' were excluded from the correlations (therefore $n$ is different between each scorer in this test). Blue filled circles are scores for a given image and red lines are from a linear model fitted by least squares. 


\section{Table S1.}

Descriptive summary of the tree species sample monitored as part of the Lopé National Park long-term observational phenology study (1986-2018) and included in this analysis of change in plant reproduction over time. Important elephant fruit species are those that bear fruit important in forest elephant diet, previously identified during a 30-month dung study and an 8-year observational diet study at Lopé (9)

\begin{tabular}{lll}
\hline Subset & All species & $\begin{array}{l}\text { Important elephant fruit } \\
\text { species }\end{array}$ \\
\hline $\begin{array}{l}\text { Total number of species } \\
\text { Total number of trees }\end{array}$ & 73 & 14 \\
$\begin{array}{l}\text { Mean length observation period (range) } \\
\text { Mean number of trees per species }\end{array}$ & 2007 & 466 \\
$\begin{array}{l}\text { (range) } \\
\text { Number of species monitored }\end{array}$ & $27(3-120)$ & $131(1-395)$ \\
consistently from 1986 - 2018 & 40 & $73(7-120)$ \\
\hline
\end{tabular}




\section{Table S2.}

Descriptive summaries for species monitored as part of a long-term observational phenology study at Lopé NP, Gabon (1986-2018), and included in this analysis of change in plant reproduction over time. Elephant fruit species include all those previously identified as consumed by elephants during a 30-month dung study and an 8-year observational diet study at Lopé (9). Important elephant fruit species (indicated by asterisks) were found in $>5 \%$ dung piles or for $>6$ months in a 30-month study of elephant dung at the site from Jan 1989 - July 1991 (9).

\begin{tabular}{|c|c|c|c|c|c|c|c|}
\hline Species & Family & Trees & Start & End & $\begin{array}{l}\text { Mean obs. } \\
\text { (min-max) }\end{array}$ & $\begin{array}{l}\text { Ele. } \\
\text { Fruit? }\end{array}$ & \\
\hline $\begin{array}{c}\text { Aframomum } \\
\text { sericeum }\end{array}$ & $\mathrm{ZING}$ & 50 & Mar-02 & Nov-18 & $\begin{array}{l}23(13- \\
190)\end{array}$ & & \\
\hline $\begin{array}{l}\text { Annickia } \\
\text { chlorantha }\end{array}$ & ANNO & 18 & Oct-86 & Aug-19 & $197(11-395)$ & & \\
\hline $\begin{array}{l}\text { Antidesma } \\
\text { rufescens }\end{array}$ & EUPH & 25 & Mar-01 & Feb-16 & $\begin{array}{l}33(14- \\
165)\end{array}$ & & \\
\hline $\begin{array}{l}\text { Antidesma } \\
\quad \text { vogelianum }\end{array}$ & EUPH & 68 & Oct-86 & Aug-19 & $\begin{array}{l}102(1- \\
395)\end{array}$ & TRUE & $* *$ \\
\hline $\begin{array}{l}\text { Aucoumea } \\
\text { klaineana }\end{array}$ & BURS & 45 & Apr-95 & Aug-19 & $235(25-293)$ & & \\
\hline $\begin{array}{l}\text { Baillonella } \\
\quad \text { toxisperma }\end{array}$ & SAPO & 13 & Aug-03 & Aug-19 & $\begin{array}{l}122(42- \\
193)\end{array}$ & TRUE & \\
\hline Beilschmeidia fulva & LAUR & 11 & Oct-86 & Aug-19 & $134(20-387)$ & & \\
\hline $\begin{array}{l}\text { Bobgunnia } \\
\quad \text { fistuloides }\end{array}$ & FABA & 14 & Jan-02 & Aug-19 & $\begin{array}{l}147(11- \\
212)\end{array}$ & TRUE & $* *$ \\
\hline $\begin{array}{l}\text { Canarium } \\
\quad \text { schweinfurthii }\end{array}$ & BURS & 21 & Oct-86 & Aug-19 & $\begin{array}{l}180(11- \\
395)\end{array}$ & TRUE & \\
\hline Celtis tessmannii & ULMA & 12 & Oct-86 & Aug-19 & $330(42-395)$ & & \\
\hline $\begin{array}{l}\text { Chrysophyllus } \\
\text { africanum }\end{array}$ & SAPO & 12 & Oct-86 & Aug-19 & $\begin{array}{l}170(42- \\
370)\end{array}$ & TRUE & \\
\hline $\begin{array}{c}\text { Chrysophyllus } \\
\text { subnudum }\end{array}$ & SAPO & 3 & Oct-86 & Aug-19 & $\begin{array}{l}260(113- \\
395)\end{array}$ & TRUE & \\
\hline Cissus dinklagei & VITA & 14 & Oct-86 & Aug-19 & $254(16-395)$ & & \\
\hline Cola lizae & STER & 22 & Oct-86 & Aug-19 & $213(28-395)$ & & \\
\hline $\begin{array}{l}\text { Dacryodes } \\
\text { buettneri }\end{array}$ & BURS & 14 & Oct-86 & Aug-19 & $298(42-395)$ & & \\
\hline $\begin{array}{l}\text { Dacryodes } \\
\quad \text { normandii }\end{array}$ & BURS & 17 & Jan-90 & Aug-19 & $\begin{array}{l}63(11- \\
356)\end{array}$ & TRUE & \\
\hline $\begin{array}{l}\text { Detarium } \\
\qquad \text { macrocarpum }\end{array}$ & FABA & 24 & Oct-86 & Aug-19 & $\begin{array}{l}229(28- \\
395)\end{array}$ & TRUE & \\
\hline
\end{tabular}




\begin{tabular}{|c|c|c|c|c|c|c|c|}
\hline Species & Family & Trees & Start & End & $\begin{array}{l}\text { Mean obs. } \\
\text { (min-max) }\end{array}$ & $\begin{array}{l}\text { Ele. } \\
\text { Fruit? }\end{array}$ & \\
\hline Dialium lopense & FABA & 87 & Oct-86 & Aug-19 & $\begin{array}{l}105(1- \\
395)\end{array}$ & & \\
\hline Diospyros dendo & EBEN & 66 & Oct-86 & Aug-19 & $\begin{array}{l}130(28- \\
395)\end{array}$ & TRUE & \\
\hline Diospyros mannii & EBEN & 19 & Oct- 86 & Aug-19 & $159(11-395)$ & & \\
\hline $\begin{array}{l}\text { Diospyros } \\
\quad \text { polystemon }\end{array}$ & EBEN & 54 & Oct- 86 & Aug-19 & $\begin{array}{l}114(6- \\
395)\end{array}$ & TRUE & \\
\hline Diospyros zenkeri & EBEN & 55 & Oct- 86 & Aug-19 & $\begin{array}{l}81(11- \\
395)\end{array}$ & & \\
\hline $\begin{array}{l}\text { Duboscia } \\
\quad \text { macrocarpa }\end{array}$ & TILI & 16 & Oct-86 & Aug-19 & $\begin{array}{l}247(42- \\
395)\end{array}$ & TRUE & $* *$ \\
\hline Ficus bubu & MORA & 3 & Jan-94 & Aug-19 & $\begin{array}{l}103(3- \\
153)\end{array}$ & & \\
\hline Ficus тисияо & MORA & 4 & Oct-86 & Aug-19 & $\begin{array}{l}226(41- \\
395)\end{array}$ & TRUE & \\
\hline $\begin{array}{l}\text { Ficus } \\
\quad \text { pseudomangifera }\end{array}$ & MORA & 6 & Jun-96 & Dec-98 & $31(31-31)$ & & \\
\hline Ficus recurvata & MORA & 11 & Oct-86 & Aug-19 & $\begin{array}{l}203(61- \\
395)\end{array}$ & TRUE & \\
\hline $\begin{array}{l}\text { Ficus } \\
\qquad \text { subsagittifolia }\end{array}$ & MORA & 3 & Jun-96 & Aug-19 & $\begin{array}{l}136(4- \\
253)\end{array}$ & & \\
\hline $\begin{array}{l}\text { Ganophyllum } \\
\text { giganteum }\end{array}$ & SAPI & 16 & Oct-86 & Aug-19 & $244(40-395)$ & & \\
\hline $\begin{array}{l}\text { Greenwayodendron } \\
\text { suaveolens }\end{array}$ & ANNO & 15 & Oct-86 & Aug-19 & $242(11-395)$ & & \\
\hline $\begin{array}{l}\text { Guibourtia } \\
\text { tessmannii }\end{array}$ & FABA & 10 & Oct-86 & Aug-19 & $152(11-395)$ & & \\
\hline Heisteria parvifolia & OLAC & 12 & Oct-86 & Aug-19 & $355(11-395)$ & & \\
\hline Irvingia gabonensis & IRVI & 27 & Oct-86 & Aug-19 & $\begin{array}{l}238(28- \\
395)\end{array}$ & TRUE & $* *$ \\
\hline Irvingia grandifolia & IRVI & 34 & Oct- 86 & Aug-19 & $\begin{array}{l}183(28- \\
395)\end{array}$ & TRUE & \\
\hline $\begin{array}{l}\text { Klainedoxa } \\
\quad \text { gabonensis }\end{array}$ & IRVI & 14 & Oct- 86 & Aug-19 & $\begin{array}{l}286(11- \\
395)\end{array}$ & TRUE & $* *$ \\
\hline Lannea welwitschii & ANAC & 3 & Feb-03 & Oct-04 & $19(16-20)$ & & \\
\hline $\begin{array}{l}\text { Lecaniodiscus } \\
\text { cupaniodes }\end{array}$ & SAPI & 7 & Oct-86 & Aug-19 & $230(18-395)$ & & \\
\hline
\end{tabular}




\begin{tabular}{|c|c|c|c|c|c|c|c|}
\hline Species & Family & Trees & Start & End & $\begin{array}{l}\text { Mean obs. } \\
\text { (min-max) }\end{array}$ & $\begin{array}{l}\text { Ele. } \\
\text { Fruit? }\end{array}$ & \\
\hline Mammea africana & CALO & 13 & Oct-86 & Aug-19 & $\begin{array}{l}153(11- \\
395)\end{array}$ & TRUE & \\
\hline Mangifera indica & ANAC & 6 & Oct-86 & Aug-19 & $\begin{array}{l}185(27- \\
395)\end{array}$ & TRUE & \\
\hline Maranthes glabra & CHRY & 10 & Oct-86 & Aug-19 & $352(11-395)$ & & \\
\hline $\begin{array}{l}\text { Massularia } \\
\text { acuminata }\end{array}$ & RUBI & 13 & Aug-03 & Aug-19 & $\begin{array}{l}160(42- \\
193)\end{array}$ & TRUE & $* *$ \\
\hline Milicia excelsa & MORA & 14 & Oct-86 & Aug-19 & $282(11-395)$ & & \\
\hline $\begin{array}{c}\text { Monanthotaxis } \\
\text { congoensis }\end{array}$ & ANNO & 46 & Jan-88 & Aug-19 & $96(8-380)$ & TRUE & \\
\hline $\begin{array}{l}\text { Myrianthus } \\
\text { arboreus }\end{array}$ & MORA & 21 & Oct-86 & Aug-19 & $\begin{array}{l}170(11- \\
395)\end{array}$ & TRUE & \\
\hline Nauclea diderrichii & RUBI & 19 & Oct-86 & Aug-19 & $\begin{array}{l}257(43- \\
395)\end{array}$ & TRUE & \\
\hline $\begin{array}{l}\text { Nauclea } \\
\quad \text { vanderguchtii }\end{array}$ & RUBI & 6 & Oct-86 & Aug-19 & $\begin{array}{l}370(325- \\
395)\end{array}$ & TRUE & \\
\hline $\begin{array}{c}\text { Omphalocarpum } \\
\text { procerum }\end{array}$ & SAPO & 7 & Apr-01 & Aug-19 & $\begin{array}{l}185(143- \\
221)\end{array}$ & TRUE & $* *$ \\
\hline Ongokea gore & OLAC & 15 & Oct-86 & Aug-19 & $\begin{array}{l}253(11- \\
395)\end{array}$ & TRUE & \\
\hline Panda oleosa & PAND & 12 & Apr-01 & Aug-19 & $\begin{array}{l}206(193- \\
221)\end{array}$ & TRUE & $* *$ \\
\hline Parkia bicolor & FABA & 11 & Oct-86 & Aug-19 & $\begin{array}{l}353(42- \\
395)\end{array}$ & TRUE & \\
\hline $\begin{array}{l}\text { Pentaclethra } \\
\text { macrophylla }\end{array}$ & FABA & 62 & Jun-96 & Aug-19 & $\begin{array}{l}113(8- \\
279)\end{array}$ & & \\
\hline $\begin{array}{l}\text { Pentadesma } \\
\text { butyracea }\end{array}$ & CLUS & 15 & Oct-86 & Aug-19 & $\begin{array}{l}282(42- \\
395)\end{array}$ & TRUE & $* *$ \\
\hline $\begin{array}{l}\text { Porterandia } \\
\text { cladantha }\end{array}$ & RUBI & 20 & Oct-86 & Aug-19 & $\begin{array}{l}196(3- \\
395)\end{array}$ & & \\
\hline $\begin{array}{c}\text { Pseudospondias } \\
\text { microcarpa }\end{array}$ & ANAC & 59 & Oct- 86 & Aug-19 & $\begin{array}{l}83(11- \\
395)\end{array}$ & TRUE & \\
\hline Psidium guineense & MYRT & 103 & Oct-86 & Feb-16 & $57(2-353)$ & TRUE & $* *$ \\
\hline $\begin{array}{l}\text { Psychotria } \\
\text { vogeliana }\end{array}$ & RUBI & 119 & Jan-88 & Feb-16 & $68(1-338)$ & TRUE & \\
\hline $\begin{array}{c}\text { Pterocarpus } \\
\text { soyauxii }\end{array}$ & FABA & 12 & Oct- 86 & Aug-19 & $336(42-395)$ & & \\
\hline
\end{tabular}




\begin{tabular}{|c|c|c|c|c|c|c|c|}
\hline Species & Family & Trees & Start & End & $\begin{array}{l}\text { Mean obs. } \\
\text { (min-max) }\end{array}$ & $\begin{array}{l}\text { Ele. } \\
\text { Fruit? }\end{array}$ & \\
\hline $\begin{array}{l}\text { Pycnanthus } \\
\text { angolensis }\end{array}$ & MYRI & 40 & Oct-86 & Aug-19 & $114(11-395)$ & & \\
\hline $\begin{array}{l}\text { Sacoglottis } \\
\text { gabonensis }\end{array}$ & HUMI & 19 & Oct-86 & Aug-19 & $\begin{array}{l}216(169- \\
395)\end{array}$ & TRUE & $* *$ \\
\hline Santiria trimera & BURS & 47 & Oct-86 & Aug-19 & $\begin{array}{l}80(10- \\
395)\end{array}$ & & \\
\hline $\begin{array}{l}\text { Sarcocephalus } \\
\quad \text { latifolius }\end{array}$ & RUBI & 23 & Jun-96 & Dec-98 & $30(29-31)$ & & \\
\hline $\begin{array}{l}\text { Scyphocephalium } \\
\text { ochocoa }\end{array}$ & MYRI & 11 & Oct-86 & Aug-19 & $210(10-395)$ & & \\
\hline Scytopetalum spp & SCYT & 4 & Sep-93 & Aug-19 & $166(18-312)$ & & \\
\hline $\begin{array}{l}\text { Staudtia } \\
\quad \text { kamerunensis } \\
\quad \text { var. gabonensis }\end{array}$ & MYRI & 13 & Oct-86 & Aug-19 & $\begin{array}{l}302(11- \\
395)\end{array}$ & TRUE & \\
\hline $\begin{array}{l}\text { Synsepalum } \\
\text { brevipes }\end{array}$ & SAPO & 28 & Mar-01 & Oct-04 & $21(14-44)$ & & \\
\hline $\begin{array}{l}\text { Tetrapleura } \\
\text { tetraptera }\end{array}$ & FABA & 21 & Mar-01 & Aug-19 & $\begin{array}{l}188(21- \\
221)\end{array}$ & TRUE & $* *$ \\
\hline $\begin{array}{r}\text { Trichoscypha } \\
\text { acuminata }\end{array}$ & ANAC & 18 & Oct-86 & Aug-19 & $\begin{array}{l}217(11- \\
395)\end{array}$ & TRUE & \\
\hline Uapaca guineensis & EUPH & 120 & Oct-86 & Aug-19 & $83(8-395)$ & TRUE & $* *$ \\
\hline $\begin{array}{l}\text { Uvariastrum } \\
\text { pierreanum }\end{array}$ & ANNO & 17 & Oct-86 & Aug-19 & $\begin{array}{l}227(11- \\
395)\end{array}$ & TRUE & $* *$ \\
\hline Vitex doniana & VERB & 86 & Oct-86 & Aug-19 & $105(16-395)$ & & \\
\hline Xylopia aethiopica & ANNO & 58 & Oct-86 & Aug-19 & $\begin{array}{l}69(11- \\
395)\end{array}$ & & \\
\hline $\begin{array}{l}\text { Xylopia } \\
\quad \text { hypolampra }\end{array}$ & ANNO & 28 & Oct-86 & Aug-19 & $155(28-395)$ & & \\
\hline Xylopia quintasii & ANNO & 46 & Oct-86 & Aug-19 & $95(7-395)$ & & \\
\hline
\end{tabular}

NB/ Trees $=$ Number of individual trees monitored per species; Start $=$ Date of first observation for that species; End = Date of most recent observation for that species; Mean obs. = Mean number of continuous monthly observations per tree for each species; Ele. Fruit? = Inidcates whether the species have fruit known to be eaten by elephants; $* *=$ Important elephant fruit. 


\section{Table S3.}

Summary of all candidate models used to analyse changes in plant reproduction over time at Lopé NP, Gabon (1986-2018). Within each set, models are compared using AIC and the model with the lowest AIC is listed first in each set. Model sets A to D include random slopes for Tree and Species by Year and random intercepts for Month. Model set E includes random slopes for Tree and Species by Year and Month as a fixed effect predictor interacting with Year. Year was retained in all top models indicating that there has been a significant change in the probability of encountering flowers and fruit over time.

\begin{tabular}{|c|c|c|c|c|c|c|c|}
\hline Model set & Response & Dataset & Obs. & Predictors & DF & AIC & $\begin{array}{l}\Delta \\
\mathbf{A I C}\end{array}$ \\
\hline \multirow[t]{2}{*}{ A } & \multirow[t]{2}{*}{ Flowers } & \multirow{2}{*}{$\begin{array}{l}\text { All spp. } \\
(\mathrm{n}=73)\end{array}$} & \multirow[t]{2}{*}{260431} & Intercept + Year & 9 & 166684.0 & 0.0 \\
\hline & & & & Intercept only & 4 & 169041.3 & 2357.3 \\
\hline \multirow[t]{2}{*}{ B } & \multirow[t]{2}{*}{ Unripe fruit } & \multirow{2}{*}{$\begin{array}{l}\text { All spp. } \\
(n=73)\end{array}$} & \multirow[t]{2}{*}{260431} & Intercept + Year & 9 & 217441.8 & 0.0 \\
\hline & & & & Intercept only & 4 & 221304.8 & 3863.0 \\
\hline \multirow[t]{2}{*}{$\mathrm{C}$} & \multirow[t]{2}{*}{ Ripe fruit } & \multirow{2}{*}{$\begin{array}{l}\text { All spp. } \\
(n=73)\end{array}$} & \multirow[t]{2}{*}{260431} & Intercept + Year & 9 & 113851.3 & 0.0 \\
\hline & & & & Intercept only & 4 & 117032.9 & 3181.6 \\
\hline \multirow[t]{2}{*}{$\mathrm{D}$} & \multirow[t]{2}{*}{ Ripe fruit } & \multirow{2}{*}{$\begin{array}{l}\text { Important } \\
\text { ele. spp. } \\
(n=14)\end{array}$} & \multirow[t]{2}{*}{58319} & Intercept + Year & 9 & 34894.9 & 0.0 \\
\hline & & & & Intercept only & 4 & 36300.0 & 1405.1 \\
\hline \multirow[t]{2}{*}{$\mathrm{E}$} & \multirow[t]{2}{*}{ Ripe fruit } & Important & 58319 & Year * Month & 30 & 34664.0 & 0.0 \\
\hline & & $\begin{array}{l}\text { ele. spp. } \\
(n=14)\end{array}$ & & Year + Month & 19 & 34848.9 & 184.9 \\
\hline
\end{tabular}

Obs. $=$ Number of observations; $\mathrm{DF}=$ Degrees of freedom; AIC $=$ Akaike's Information Criterion; $\triangle \mathrm{AIC}=$ difference in AIC compared to best model. 


\section{Table S4.}

Summary of model coefficients from the best models in each model set (Table S3) for the analysis of change in plant reproduction over time at Lopé NP, Gabon (1986-2018). Models A to $\mathrm{D}$ include random slopes for Tree and Species by Year and random intercepts for Month. Model E includes random slopes for Tree and Species by Year and Month as a fixed effect predictor interacting with Year. The estimate for Year is negative in each case indicating that the probability of encountering flowers and fruit have declined over time.

\begin{tabular}{|c|c|c|c|c|c|c|c|c|}
\hline Model & Response & Dataset & Term & Est. & $\mathbf{S E}$ & $\mathbf{Z}$ & $\begin{array}{l}-95 \% \\
\text { CI }\end{array}$ & $+95 \%$ CI \\
\hline \multirow[t]{2}{*}{ A } & \multirow[t]{2}{*}{ Flowers } & \multirow{2}{*}{$\begin{array}{l}\text { All spp. } \\
(\mathrm{n}=73)\end{array}$} & Intercept & -2.54 & 0.19 & -13.44 & -2.91 & -2.17 \\
\hline & & & Year & -0.28 & 0.04 & -7.88 & -0.35 & -0.21 \\
\hline \multirow[t]{2}{*}{ B } & \multirow{2}{*}{$\begin{array}{l}\text { Unripe } \\
\text { fruit }\end{array}$} & \multirow{2}{*}{$\begin{array}{l}\text { All spp. } \\
(n=73)\end{array}$} & Intercept & -1.98 & 0.16 & -12.64 & -2.29 & -1.67 \\
\hline & & & Year & -0.24 & 0.04 & -5.62 & -0.32 & -0.15 \\
\hline \multirow[t]{2}{*}{$\mathrm{C}$} & \multirow[t]{2}{*}{ Ripe fruit } & \multirow{2}{*}{$\begin{array}{l}\text { All spp. } \\
(n=73)\end{array}$} & Intercept & -3.29 & 0.16 & -20.74 & -3.6 & -2.98 \\
\hline & & & Year & -0.51 & 0.05 & -10.92 & -0.6 & -0.42 \\
\hline \multirow[t]{2}{*}{ D } & \multirow[t]{2}{*}{ Ripe fruit } & \multirow{2}{*}{$\begin{array}{l}\text { Important } \\
\text { ele. spp. } \\
(n=14)\end{array}$} & Intercept & -2.53 & 0.34 & -7.41 & -3.2 & -1.86 \\
\hline & & & Year & -0.7 & 0.11 & -6.53 & -0.91 & -0.49 \\
\hline \multirow[t]{12}{*}{$\mathrm{E}$} & \multirow[t]{12}{*}{ Ripe fruit } & \multirow{12}{*}{$\begin{array}{l}\text { Important } \\
\text { ele. spp. } \\
(n=14)\end{array}$} & Intercept & -2.46 & 0.30 & -8.21 & -3.05 & -1.87 \\
\hline & & & Year & -0.78 & 0.12 & -6.49 & -1.01 & -0.54 \\
\hline & & & $\begin{array}{l}\text { Month } \\
\text { (Feb) }\end{array}$ & -0.18 & 0.07 & -2.54 & -0.32 & -0.04 \\
\hline & & & $\begin{array}{l}\text { Month } \\
\text { (Mar) }\end{array}$ & 0.30 & 0.07 & 4.56 & 0.17 & 0.43 \\
\hline & & & $\begin{array}{l}\text { Month } \\
\text { (Apr) }\end{array}$ & 0.12 & 0.07 & 1.69 & -0.02 & 0.25 \\
\hline & & & $\begin{array}{l}\text { Month } \\
\text { (May) }\end{array}$ & -0.52 & 0.08 & -6.82 & -0.67 & -0.37 \\
\hline & & & $\begin{array}{l}\text { Month } \\
\text { (Jun) }\end{array}$ & -1.18 & 0.09 & -13.22 & -1.35 & -1.00 \\
\hline & & & $\begin{array}{l}\text { Month } \\
\text { (Jul) }\end{array}$ & -0.91 & 0.08 & -10.84 & -1.07 & -0.74 \\
\hline & & & $\begin{array}{l}\text { Month } \\
\text { (Aug) }\end{array}$ & -0.33 & 0.07 & -4.54 & -0.47 & -0.19 \\
\hline & & & $\begin{array}{l}\text { Month } \\
\text { (Sep) }\end{array}$ & 0.26 & 0.07 & 3.86 & 0.13 & 0.39 \\
\hline & & & $\begin{array}{l}\text { Month } \\
\text { (Oct) }\end{array}$ & 0.62 & 0.06 & 9.58 & 0.49 & 0.74 \\
\hline & & & $\begin{array}{l}\text { Month } \\
\text { (Nov) }\end{array}$ & 0.57 & 0.07 & 8.68 & 0.45 & 0.70 \\
\hline
\end{tabular}




\begin{tabular}{|c|c|c|c|c|c|c|c|c|}
\hline Model & Response & Dataset & Term & Est. & SE & $\mathbf{Z}$ & $\begin{array}{l}-95 \% \\
\text { CI }\end{array}$ & $+95 \% \mathrm{CI}$ \\
\hline & & & $\begin{array}{l}\text { Month } \\
\text { (Dec) }\end{array}$ & 0.40 & 0.07 & 5.90 & 0.27 & 0.53 \\
\hline & & & $\begin{array}{l}\text { Year: } \\
\text { Month } \\
\text { (Feb) }\end{array}$ & 0.09 & 0.07 & 1.28 & -0.05 & 0.24 \\
\hline & & & $\begin{array}{l}\text { Year: } \\
\text { Month } \\
\text { (Mar) }\end{array}$ & 0.02 & 0.07 & 0.33 & -0.11 & 0.16 \\
\hline & & & $\begin{array}{l}\text { Year: } \\
\text { Month } \\
\text { (Apr) }\end{array}$ & 0.22 & 0.07 & 3.12 & 0.08 & 0.36 \\
\hline & & & $\begin{array}{l}\text { Year: } \\
\text { Month } \\
\text { (May) }\end{array}$ & 0.21 & 0.08 & 2.68 & 0.06 & 0.37 \\
\hline & & & $\begin{array}{l}\text { Year: } \\
\text { Month } \\
\text { (Jun) }\end{array}$ & 0.43 & 0.10 & 4.52 & 0.24 & 0.62 \\
\hline & & & $\begin{array}{l}\text { Year: } \\
\text { Month } \\
\text { (Jul) }\end{array}$ & 0.50 & 0.09 & 5.71 & 0.33 & 0.67 \\
\hline & & & $\begin{array}{l}\text { Year: } \\
\text { Month } \\
\text { (Aug) }\end{array}$ & 0.37 & 0.08 & 4.81 & 0.22 & 0.51 \\
\hline & & & $\begin{array}{l}\text { Year: } \\
\text { Month } \\
\text { (Sep) }\end{array}$ & 0.30 & 0.07 & 4.22 & 0.16 & 0.43 \\
\hline & & & $\begin{array}{l}\text { Year: } \\
\text { Month } \\
\text { (Oct) }\end{array}$ & 0.05 & 0.07 & 0.68 & -0.08 & 0.17 \\
\hline & & & $\begin{array}{l}\text { Year: } \\
\text { Month } \\
\text { (Nov) }\end{array}$ & -0.26 & 0.07 & -3.87 & -0.39 & -0.13 \\
\hline & & & $\begin{array}{l}\text { Year: } \\
\text { Month } \\
\text { (Dec) }\end{array}$ & -0.18 & 0.07 & -2.67 & -0.32 & -0.05 \\
\hline
\end{tabular}




\section{Table S5.}

Summary table of the random coefficients for the Species grouping factor from a generalized linear mixed model assessing change in probability of encountering ripe fruit over time at Lopé NP, Gabon (1986-2018; model C in Tables S3, S4, S10). This table shows species arranged in order from the most negative slope for Year to the most positive $(n=73)$. Species vary in the strength of their response over time indicating biological differences.

\begin{tabular}{llrl}
\hline Level & Group & Intercept & Year \\
\hline Pentaclethra macrophylla & Species & -3.59 & -1.62 \\
Tetrapleura tetraptera & Species & -1.78 & -1.35 \\
Cissus dinklagei & Species & -3.09 & -1.14 \\
Ficus subsagittifolia & Species & -3.71 & -0.94 \\
Omphalocarpum procerum & Species & -1.12 & -0.91 \\
Panda oleosa & Species & -2.61 & -0.88 \\
Vitex doniana & Species & -3.32 & -0.86 \\
Ficus mucuso & Species & -2.95 & -0.84 \\
Klainedoxa gabonensis & Species & -3.09 & -0.81 \\
Ongokea gore & Species & -4.24 & -0.81 \\
Psidium guineense & Species & -3.31 & -0.81 \\
Ficus bubu & Species & -3.61 & -0.75 \\
Scytopetalum spp & Species & -3.25 & -0.74 \\
Uapaca guineensis & Species & -2.33 & -0.72 \\
Sacoglottis gabonensis & Species & -1.39 & -0.71 \\
Sarcocephalus latifolius & Species & -3.08 & -0.71 \\
Bobgunnia fistuloides & Species & -2.38 & -0.69 \\
Duboscia macrocarpa & Species & -2.13 & -0.69 \\
Pseudospondias microcarpa & Species & -3.57 & -0.69 \\
Beilschmeidia fulva & Species & -3.95 & -0.68 \\
Lecaniodiscus cupaniodes & Species & -4.22 & -0.68 \\
Antidesma vogelianum & Species & -1.15 & -0.66 \\
Chrysophyllus africanum & Species & -2.81 & -0.66 \\
Dialium lopense & Species & -2.98 & -0.65 \\
Ficus recurvata & Species & -4.05 & -0.65 \\
Myrianthus arboreus & Species & -3.61 & -0.63 \\
Mangifera indica & Species & -4.04 & -0.62 \\
Antidesma rufescens & Species & -3.13 & -0.61 \\
Annickia chlorantha & Species & -3.27 & -0.59 \\
Synsepalum brevipes & Species & -3.73 & -0.56 \\
Maranthes glabra & Species & -3.23 & -0.55 \\
Ficus pseudomangifera & Species & -2.58 & -0.53 \\
Scyphocephalium ochocoa & Species & -3.70 & -0.53 \\
\hline & & & \\
& & & \\
& & &
\end{tabular}




\begin{tabular}{llrl}
\hline Level & Group & Intercept & Year \\
\hline Parkia bicolor & Species & -3.56 & -0.52 \\
Xylopia quintasii & Species & -3.24 & -0.52 \\
Nauclea vanderguchtii & Species & -2.81 & -0.50 \\
Psychotria vogeliana & Species & -2.22 & -0.50 \\
Heisteria parvifolia & Species & -3.09 & -0.48 \\
Pentadesma butyracea & Species & -2.23 & -0.48 \\
Xylopia aethiopica & Species & -3.34 & -0.48 \\
Lannea welwitschii & Species & -3.67 & -0.47 \\
Greenwayodendron suaveolens & Species & -3.51 & -0.46 \\
Nauclea diderrichii & Species & -3.06 & -0.43 \\
Staudtia kamerunensis var. & Species & -2.84 & -0.43 \\
gabonensis & Species & -3.53 & -0.41 \\
Aframomum sericeum & Species & -2.09 & -0.40 \\
Monanthotaxis congoensis & Species & -3.67 & -0.40 \\
Pterocarpus soyauxii & Species & -3.20 & -0.39 \\
Uvariastrum pierreanum & Species & -3.58 & -0.38 \\
Diospyros dendo & Species & -2.50 & -0.34 \\
Pycnanthus angolensis & Species & -4.07 & -0.34 \\
Santiria trimera & Species & -4.39 & -0.33 \\
Celtis tessmannii & Species & -1.88 & -0.33 \\
Detarium macrocarpum & Species & -3.15 & -0.32 \\
Cola lizae & Species & -3.50 & -0.30 \\
Diospyros mannii & Species & -2.99 & -0.26 \\
Canarium schweinfurthii & Species & -3.90 & -0.26 \\
Mammea africana & Species & -5.72 & -0.26 \\
Trichoscypha acuminata & Species & -5.11 & -0.23 \\
Milicia excelsa & Species & -1.73 & -0.23 \\
Porterandia cladantha & Species & -4.75 & -0.21 \\
Aucoumea klaineana & Species & -3.58 & -0.21 \\
Dacryodes normandii & Species & -0.74 & -0.21 \\
Xylopia hypolampra & Species & -3.27 & -0.20 \\
Ganophyllum giganteum & Species & -3.48 & -0.17 \\
Chrysophyllus subnudum & Species & -3.59 & -0.16 \\
Diospyros polystemon & Species & -3.24 & -0.14 \\
Irvingia gabonensis & Species & -4.35 & -0.13 \\
Irvingia grandifolia & Species & -3.25 & -0.11 \\
Baillonella toxisperma & Species & -4.84 & -0.11 \\
Massularia acuminata & -3.78 & -0.10 \\
Diospyros zenkeri & & & \\
\hline & & & \\
& & &
\end{tabular}




\begin{tabular}{llrr}
\hline Level & Group & Intercept & Year \\
\hline Guibourtia tessmannii & Species & -3.58 & -0.09 \\
Dacryodes buettneri & Species & -4.62 & 0.22 \\
\hline
\end{tabular}




\section{Table S6.}

Summary table of coefficients (estimates) from the top linear mixed effects models showing the relationship between elephant Body Condition Score and Age (Adult, Immature or Infant), Year (mean-centred and scaled by 1 SD) and Month (categorical) in three time periods (1997 to 2018, 1997 to 2007 and 2008 to 2018). Models were fitted with a Gaussian error structure. Photo Event and Scorer ID were included as random intercepts in all models to account for pseudoreplication. Standard errors (SE), degrees of freedom (DF) and bootstrapped 95\% confidence intervals (CI; 1000 replicates) are also given. For the period 1997 to 2007, no data were available for the months of December and January. The intercept is for the earliest month in a given time period, and for an Adult if Age was in the top model. The estimate for Year is negative for the full time period (1997-2018) and for the later time period (2008-2018) but depends on elephant Age for the earlier time period (1997-2007). It is only in the latter time period that confidence intervals do not cross zero indicating greater confidence in the decline.

\begin{tabular}{llllll}
\hline Variable & Estimate & SE & DF & $-95 \%$ CI & $+95 \%$ CI \\
\hline
\end{tabular}

1997 to 2018

$\begin{array}{lccccc}\text { Intercept } & 4.73 & 0.40 & 5270 & 3.89 & 5.55 \\ \text { Year } & -0.06 & 0.04 & 5270 & -0.14 & 0.01 \\ \text { Month Feb } & -0.08 & 0.36 & 5270 & -0.77 & 0.64 \\ \text { Month Mar } & -0.06 & 0.37 & 5270 & -0.82 & 0.69 \\ \text { Month Apr } & -0.56 & 0.33 & 5270 & -1.24 & 0.09 \\ \text { Month May } & -0.35 & 0.34 & 5270 & -1.04 & 0.31 \\ \text { Month Jun } & -0.54 & 0.35 & 5270 & -1.21 & 0.12 \\ \text { Month Jul } & -0.26 & 0.32 & 5270 & -0.93 & 0.41 \\ \text { Month Aug } & -0.17 & 0.32 & 5270 & -0.80 & 0.45 \\ \text { Month Sept } & -0.03 & 0.30 & 5270 & -0.65 & 0.60 \\ \text { Month Oct } & -0.06 & 0.30 & 5270 & -0.67 & 0.57 \\ \text { Month Nov } & 0.03 & 0.30 & 5270 & -0.59 & 0.69 \\ \text { Month Dec } & -0.07 & 0.31 & 5270 & -0.70 & 0.59\end{array}$

1997 to 2007

Intercept

Age Immature

Age Infant

Year

Month Mar

Month Apr

Month May

Month Jun
4.94

0.02

$-0.15$

0.13

$-0.58$

$-0.76$

$-0.51$

$-0.71$

\subsection{0}

2383

4.15

$-0.17$

$-0.62$

0.00

$-1.59$

$-1.37$

$-1.24$

$-1.49$
5.77

0.21

0.35

0.27

0.35

$-0.14$

0.19 


\begin{tabular}{|c|c|c|c|c|c|}
\hline Variable & Estimate & SE & DF & $-95 \%$ CI & $+95 \% \mathrm{CI}$ \\
\hline Month Jul & -0.44 & 0.33 & 2383 & -1.09 & 0.18 \\
\hline Month Aug & -0.01 & 0.43 & 2383 & -0.89 & 0.82 \\
\hline Month Sept & 0.12 & 0.33 & 2383 & -0.59 & 0.76 \\
\hline Month Oct & 0.80 & 0.50 & 2383 & -0.16 & 1.83 \\
\hline Month Nov & -1.18 & 0.59 & 2383 & -2.41 & -0.07 \\
\hline Age Immature * & -0.31 & 0.10 & 2383 & -0.51 & -0.15 \\
\hline \multicolumn{6}{|l|}{ Year } \\
\hline Age Infant * Year & -0.22 & 0.45 & 2383 & -1.09 & 0.58 \\
\hline \multicolumn{6}{|l|}{2008 to 2018} \\
\hline Intercept & 4.88 & 0.42 & 2869 & 4.09 & 5.64 \\
\hline Year & -0.17 & 0.05 & 2869 & -0.27 & -0.07 \\
\hline Month Feb & 0.37 & 0.45 & 2869 & -0.56 & 1.32 \\
\hline Month Mar & 0.06 & 0.41 & 2869 & -0.77 & 0.93 \\
\hline Month Apr & -0.27 & 0.39 & 2869 & -1.07 & 0.56 \\
\hline Month May & -0.33 & 0.37 & 2869 & -1.11 & 0.42 \\
\hline Month Jun & -0.60 & 0.41 & 2869 & -1.45 & 0.24 \\
\hline Month Jul & -0.23 & 0.38 & 2869 & -1.01 & 0.57 \\
\hline Month Aug & -0.37 & 0.33 & 2869 & -1.04 & 0.32 \\
\hline Month Sept & -0.17 & 0.31 & 2869 & -0.80 & 0.46 \\
\hline Month Oct & -0.26 & 0.31 & 2869 & -0.90 & 0.37 \\
\hline Month Nov & -0.09 & 0.31 & 2869 & -0.75 & 0.54 \\
\hline Month Dec & -0.20 & 0.32 & 2869 & -0.85 & 0.46 \\
\hline
\end{tabular}


Table S7.

Total number of unique elephant photo Capture Events (identified using a 10-minute threshold between image sequences) for each month and year combination.

\begin{tabular}{rrrrrrrrrrrrr}
\hline \multicolumn{2}{c}{ Month } & & & & & & & & & & \\
Year & Jan & Feb & Mar & Apr & May & Jun & Jul & Aug & Sep & Oct & Nov & Dec \\
\hline 1997 & 0 & 0 & 0 & 0 & 0 & 0 & 4 & 0 & 7 & 1 & 0 & 0 \\
1998 & 0 & 18 & 0 & 0 & 0 & 0 & 0 & 0 & 0 & 0 & 0 & 0 \\
1999 & 0 & 0 & 0 & 1 & 0 & 0 & 0 & 0 & 1 & 2 & 3 & 0 \\
2000 & 0 & 1 & 1 & 11 & 4 & 0 & 0 & 0 & 0 & 0 & 0 & 0 \\
2001 & 0 & 0 & 0 & 0 & 0 & 1 & 2 & 1 & 2 & 0 & 0 & 0 \\
2002 & 0 & 0 & 0 & 0 & 0 & 0 & 0 & 0 & 0 & 0 & 0 & 0 \\
2003 & 0 & 0 & 0 & 0 & 0 & 0 & 0 & 0 & 0 & 1 & 0 & 0 \\
2004 & 0 & 0 & 0 & 0 & 0 & 0 & 0 & 0 & 0 & 0 & 0 & 0 \\
2005 & 0 & 0 & 0 & 4 & 0 & 1 & 0 & 4 & 0 & 1 & 0 & 0 \\
2006 & 0 & 0 & 4 & 12 & 11 & 13 & 28 & 3 & 2 & 0 & 0 & 0 \\
2007 & 0 & 0 & 0 & 0 & 0 & 0 & 0 & 0 & 4 & 0 & 0 & 0 \\
\hline 2008 & 0 & 0 & 0 & 0 & 0 & 0 & 0 & 6 & 36 & 45 & 11 & 0 \\
2009 & 0 & 1 & 2 & 0 & 1 & 0 & 0 & 1 & 0 & 2 & 0 & 0 \\
2010 & 0 & 0 & 0 & 0 & 0 & 0 & 0 & 0 & 0 & 0 & 0 & 0 \\
2011 & 0 & 0 & 0 & 0 & 0 & 0 & 0 & 0 & 0 & 0 & 0 & 0 \\
2012 & 0 & 0 & 0 & 0 & 0 & 0 & 0 & 0 & 0 & 0 & 0 & 0 \\
2013 & 0 & 0 & 0 & 0 & 0 & 0 & 0 & 0 & 34 & 117 & 112 & 57 \\
2014 & 0 & 0 & 0 & 0 & 0 & 0 & 0 & 0 & 0 & 0 & 0 & 0 \\
2015 & 3 & 0 & 0 & 0 & 0 & 0 & 0 & 0 & 0 & 0 & 0 & 0 \\
2016 & 0 & 2 & 0 & 0 & 2 & 3 & 18 & 43 & 68 & 47 & 21 & 23 \\
2017 & 12 & 7 & 14 & 18 & 20 & 12 & 0 & 0 & 0 & 0 & 0 & 0 \\
2018 & 0 & 0 & 0 & 0 & 0 & 0 & 2 & 4 & 7 & 5 & 1 & 0 \\
\hline & & & & & & & & & & & 0 \\
\hline
\end{tabular}


Table S8.

Potential direct and indirect mechanisms for population-level changes in elephant body condition.

\begin{tabular}{|c|c|c|c|}
\hline Hypothesis & $\begin{array}{l}\text { Biological/ ecological } \\
\text { summary }\end{array}$ & Context for study area & References \\
\hline $\begin{array}{l}\text { Energy } \\
\text { expenditure } \\
\text { exceeds energy } \\
\text { intake }\end{array}$ & $\begin{array}{l}\text { Reduced food } \\
\text { availability leads to } \\
\text { insufficient food to } \\
\text { support the population } \\
\text { and / or individuals } \\
\text { expend greater energy } \\
\text { finding food. Body } \\
\text { condition declines ahead } \\
\text { of population change. }\end{array}$ & $\begin{array}{l}\text { Forest elephants have a broad diet } \\
\text { that includes fruit, foliage and } \\
\text { bark. If fruit availability is low, } \\
\text { elephants may be replacing high } \\
\text { calorie fruits with other less } \\
\text { calorific forage, leading to lower } \\
\text { body condition. } \\
\text { Forest elephant movements are } \\
\text { also known to track seasonal food } \\
\text { availability and it is possible that } \\
\text { individuals are expending more } \\
\text { energy searching for food, } \\
\text { particularly during times of } \\
\text { scarcity such as the long dry } \\
\text { season between June and } \\
\text { September. There is likely to be } \\
\text { high variation among individuals, } \\
\text { however, since studies of savanna } \\
\text { elephants have shown that more } \\
\text { experienced, older mothers can } \\
\text { buffer the effects of } \\
\text { environmental stressors on their } \\
\text { calves, probably because they } \\
\text { have a greater knowledge of the } \\
\text { spatial and temporal distribution } \\
\text { of food, or because they can } \\
\text { dominate access to resources. }\end{array}$ & $(25,42,43)$ \\
\hline $\begin{array}{l}\text { Habitat } \\
\text { modification }\end{array}$ & $\begin{array}{l}\text { Landscape change due to } \\
\text { habitat loss and } \\
\text { modification can alter } \\
\text { animal behaviour, access } \\
\text { to resources and } \\
\text { resource availability. }\end{array}$ & $\begin{array}{l}\text { A relationship between body } \\
\text { condition and seasonal or human } \\
\text { induced habitat modification has } \\
\text { been reported in several large } \\
\text { mammal species, including } \\
\text { elephants. In our study area, }\end{array}$ & $(44-47)$ \\
\hline
\end{tabular}




\begin{tabular}{|c|c|c|c|}
\hline Hypothesis & $\begin{array}{l}\text { Biological/ ecological } \\
\text { summary }\end{array}$ & Context for study area & References \\
\hline & & $\begin{array}{l}\text { forest cover and land } \\
\text { management has remained } \\
\text { relatively stable during the past } \\
30 \text { years with little successional } \\
\text { change. }\end{array}$ & \\
\hline $\begin{array}{l}\text { Genetic } \\
\text { bottleneck }\end{array}$ & $\begin{array}{l}\text { Post-bottleneck } \\
\text { inbreeding results in } \\
\text { reduced fitness and body } \\
\text { condition }\end{array}$ & $\begin{array}{l}\text { There is no evidence of a } \\
\text { demographic bottleneck at Lope } \\
\text { NP. Genetic studies found that } \\
\text { genetic variability is higher in } \\
\text { forest elephants than in savanna } \\
\text { elephants; connectivity between } \\
\text { protected areas in Gabon would } \\
\text { compensate for a loss of genetic } \\
\text { diversity due to sudden } \\
\text { population decline. }\end{array}$ & $(48,49)$ \\
\hline Disease & $\begin{array}{l}\text { Changes in disease } \\
\text { prevalence (including } \\
\text { endo- and ectoparasites), } \\
\text { could cause body } \\
\text { condition to decline, } \\
\text { especially when } \\
\text { interacting with reduced } \\
\text { food availability and } \\
\text { climate change. }\end{array}$ & $\begin{array}{l}\text { Parasitism and disease prevalence } \\
\text { is closely interwoven with host } \\
\text { condition and can be a cause or a } \\
\text { consequence of decreased body } \\
\text { condition, or a combination of } \\
\text { both. Alteration of host-parasite } \\
\text { dynamics may be driven by } \\
\text { factors facilitating parasite } \\
\text { transmission, including climate } \\
\text { change and increased population } \\
\text { density or movements. Reduced } \\
\text { immunity due to reproductive } \\
\text { status or nutritional stress can } \\
\text { also increase the susceptibility of } \\
\text { hosts to infection. } \\
\text { The lack of evidence of increased } \\
\text { mortality in the last decade in the } \\
\text { study area, despite continuous }\end{array}$ & $(42,50-52)$ \\
\hline
\end{tabular}




\begin{tabular}{llll}
\hline Hypothesis & $\begin{array}{l}\text { Biological/ ecological } \\
\text { summary }\end{array}$ & Context for study area & References \\
& & $\begin{array}{l}\text { presence of researchers and } \\
\text { rangers, does not support the } \\
\text { hypothesis of an emerging } \\
\text { disease that would likely be } \\
\text { associated with high } \\
\text { pathogenicity in naïve hosts. }\end{array}$ \\
\hline Mineral/vitamin & $\begin{array}{l}\text { Elephant distribution can } \\
\text { deficiency }\end{array}$ & $\begin{array}{l}\text { Elephants range over huge areas } \\
\text { and actively seek salt and other } \\
\text { minerals. However, these }\end{array}$ \\
& $\begin{array}{l}\text { availability. Nutritional } \\
\text { deficiencies have been } \\
\text { documented to cause } \\
\text { changes in body }\end{array}$ & $\begin{array}{l}\text { geological processes operating } \\
\text { over millennial scales, and it }\end{array}$ \\
condition in other & $\begin{array}{l}\text { seems unlikely that they have } \\
\text { become depleted across the study } \\
\text { angulates. }\end{array}$ & area during a 30-year period. \\
\end{tabular}




\section{Table S9.}

Summary table showing the sample sizes of unique elephant photos scored $(n=2823)$ and details of methods used to capture elephant photos during the study period (1997 - 2018).

\begin{tabular}{|c|c|c|c|c|c|}
\hline Source & $\begin{array}{c}\text { Years } \\
\text { available }\end{array}$ & $\begin{array}{c}N \\
\text { unique }\end{array}$ & Method & Description & Reference \\
\hline Maisels, F. & 2005 & 4 & $\begin{array}{l}\text { Handheld } \\
\text { digital } \\
\text { camera }\end{array}$ & Ad-hoc & none \\
\hline $\begin{array}{l}\text { Brun-Jeffery, } \\
\text { K. }\end{array}$ & $\begin{array}{l}2005 \\
2007 \\
2008 \\
2009\end{array}$ & 288 & $\begin{array}{l}\text { Handheld } \\
\text { digital } \\
\text { camera }\end{array}$ & Ad-hoc & none \\
\hline Schuttler, S & 2008 & 87 & $\begin{array}{l}\text { Handheld } \\
\text { digital } \\
\text { camera }\end{array}$ & $\begin{array}{l}\text { Systematic study of } \\
\text { forest elephant group } \\
\text { dynamics. }\end{array}$ & $(49)$ \\
\hline Whittaker, A. & $\begin{array}{l}2005 \\
2006 \\
2008\end{array}$ & 1147 & $\begin{array}{l}\text { Handheld } \\
\text { digital } \\
\text { camera }\end{array}$ & $\begin{array}{l}\text { Systematic study of } \\
\text { forest elephant group } \\
\text { dynamics. }\end{array}$ & $(49)$ \\
\hline $\begin{array}{l}\text { Bahaa-el-din, } \\
\text { L. }\end{array}$ & 2013 & 658 & $\begin{array}{l}\text { Camera } \\
\text { traps }\end{array}$ & $\begin{array}{l}\text { Systematic study of } \\
\text { mammal communities. }\end{array}$ & $(54)$ \\
\hline Bunnefeld, N. & 2016 & 9 & $\begin{array}{l}\text { Handheld } \\
\text { digital } \\
\text { camera }\end{array}$ & Ad-hoc & none \\
\hline Cardoso, A. & $\begin{array}{l}2016 \\
2017\end{array}$ & 547 & $\begin{array}{l}\text { Camera } \\
\text { traps }\end{array}$ & $\begin{array}{l}\text { Systematic study of } \\
\text { relationship between } \\
\text { forest elephant densities } \\
\text { and seasonal fruit } \\
\text { availability. }\end{array}$ & $(26)$ \\
\hline Momont, L. & $\begin{array}{l}1999 \\
2000\end{array}$ & 22 & & & \\
\hline White, L. & $\begin{array}{l}1997, \\
1998, \\
1999\end{array}$ & 37 & $\begin{array}{l}\text { Handheld } \\
\text { digital } \\
\text { camera }\end{array}$ & $\begin{array}{l}\text { Systematic study of } \\
\text { forest elephant ecology }\end{array}$ & none \\
\hline $\begin{array}{l}\text { Whytock, R. \& } \\
\text { Momboua, B. }\end{array}$ & 2018 & 24 & $\begin{array}{l}\text { Camera } \\
\text { traps }\end{array}$ & $\begin{array}{l}\text { Systematic study of } \\
\text { mammal communities. }\end{array}$ & none \\
\hline
\end{tabular}




\section{Table S10.}

Summary table showing standard deviations and correlations of random effect terms for the best models for changes in tree reproduction over time at Lopé NP, Gabon (1986-2018). Models A to $\mathrm{D}$ include random slopes for Tree and Species by Year and random intercepts for Month. Model E includes Month as a fixed effect predictor interacting with Year and random slopes for Tree and Species by Year. Species and Tree grouping factors account for important variation in these data.

\begin{tabular}{|c|c|c|c|c|c|c|}
\hline Model & Response & Dataset & Group & $\begin{array}{l}\text { SD } \\
\text { (Intercept) }\end{array}$ & $\begin{array}{l}\text { SD } \\
\text { (Year) }\end{array}$ & Cor. \\
\hline \multirow[t]{3}{*}{$\mathrm{A}$} & Flowers & All spp. $(n=73)$ & Tree & 0.44 & 0.15 & -0.31 \\
\hline & & & Species & 1.12 & 0.27 & -0.47 \\
\hline & & & Month & 0.46 & & \\
\hline \multirow[t]{3}{*}{ B } & Unripe & All spp. $(n=73)$ & Tree & 0.84 & 0.32 & -0.36 \\
\hline & fruit & & Species & 1.25 & 0.32 & -0.6 \\
\hline & & & Month & 0.15 & & \\
\hline \multirow[t]{3}{*}{$\mathrm{C}$} & Ripe fruit & All spp. $(n=73)$ & Tree & 0.74 & 0.25 & -0.29 \\
\hline & & & Species & 0.98 & 0.35 & -0.25 \\
\hline & & & Month & 0.37 & & \\
\hline \multirow[t]{3}{*}{$\mathrm{D}$} & Ripe fruit & Important ele & Tree & 0.74 & 0.33 & -0.19 \\
\hline & & spp. $(n=14)$ & Species & 1.08 & 0.36 & -0.67 \\
\hline & & & Month & 0.58 & & \\
\hline \multirow[t]{2}{*}{$\mathrm{E}$} & Ripe fruit & Important ele & Tree & 0.75 & 0.34 & -0.25 \\
\hline & & spp. $(n=14)$ & Species & 1.08 & 0.37 & -0.71 \\
\hline
\end{tabular}

$\mathrm{NB} / \mathrm{SD}=$ Standard Deviation; Cor. $=$ Correlation. 
Table S11.

Alternative models explaining the relationship between elephant body condition (Body Score) and elephant age class (Age), Year and calendar month (Month).

\begin{tabular}{l} 
Model \\
\hline Body Score $\sim$ Month \\
Body Score $\sim$ Year + Month \\
Body Score $\sim$ Age + Year + Month \\
Body Score $\sim$ Age + Year + Age $*$ Year + Month
\end{tabular}




\section{Table S12.}

Summary table of candidate models for change in elephant body condition over time using generalised linear models with mean Body Condition Score per event as the response variable for the time-periods 1997 to 2018, 1997 to 2007 and 2008 to 2018. When models are compared using $\mathrm{AIC}_{\mathrm{c}}$, Year is retained in the best model (simplest model within 2 AICc of the top model) for the two halves of the data separately but not for the full time period (although it is a close second to the top model). This indicates that elephant body condition is likely to be changing over time although uncertainty is higher for the full time period (Table S14).

\begin{tabular}{llll}
\hline Model & df & AICc & $\Delta$ AICc \\
\hline
\end{tabular}

1997 to 2018

Month

Year + Month

Age + Year + Month

Age + Year + Age * Year + Month

1997 to 2007

Year + Month

Month

Age + Year + Month

Age + Year + Age * Year + Month
$13 \quad 2885.62$

$14 \quad 2886.41$

$16 \quad 2889.95$

$18 \quad 2893.02$
0.00

0.79

4.34

7.41

2008 to 2018

Year + Month

$\begin{array}{lll}14 & 2465.05 & 0.00\end{array}$

Month

$13 \quad 2468.51$

3.46

Age + Year + Month

$16 \quad 2468.81$

3.76

Age + Year + Age * Year + Month

$18 \quad 2472.45$

7.40 


\section{Table S13.}

Summary table of candidate models for change in elephant body condition over time using linear mixed effects models with Body Condition Score as the response variable for the time-periods 1997 to 2018, 1997 to 2007 and 2008 to 2018. Capture Event and Scorer ID were included as random intercepts in all models. When models are compared using $\mathrm{AIC}_{\mathrm{c}}$, Year is retained in the best model (simplest model within 2 AICc of the top model) for the two halves of the data separately but not for the full time period (although it is a close second to the top model). This indicates that elephant body condition is likely to be changing over time although uncertainty is higher for the full time period (Table S6).

10

\begin{tabular}{llll}
\hline Model & df & $\mathrm{AIC}_{\mathrm{c}}$ & $\Delta \mathrm{AIC}_{\mathrm{c}}$ \\
\hline
\end{tabular}

1997 to 2018

$\begin{array}{llll}\text { Year + Month } & 16 & 16919.38 & 0.00 \\ \text { Month } & 15 & 16920.32 & 0.94 \\ \text { Age + Year + Month } & 18 & 16922.25 & 2.88 \\ \text { Age + Year + Age * Year + } & 20 & 16926.11 & 6.73 \\ \text { Month } & & & \end{array}$

1997 to 2007

Age + Year + Age * Year $+\quad \begin{array}{lll}18 & 7122.52 & 0.00\end{array}$

Month

$\begin{array}{llll}\text { Year + Month } & 14 & 7126.11 & 3.59\end{array}$

$\begin{array}{llll}\text { Month } & 13 & 7126.73 & 4.21\end{array}$

Age + Year + Month $\quad 16 \quad 7129.24 \quad 6.72$

2008 to 2018

\begin{tabular}{llll} 
Year + Month & 16 & 9673.37 & 0.00 \\
Age + Year + Month & 18 & 9675.67 & 2.30 \\
Age + Year + Age * Year + & 20 & 9679.10 & 5.73 \\
$\begin{array}{l}\text { Month } \\
\text { Month }\end{array}$ & 15 & 9683.23 & 9.86 \\
\hline
\end{tabular}




\section{Table S14.}

Summary table showing coefficients (estimates) from the top general linear models for the effects of Age (Adult, Immature or Infant), Year (mean-centred and scaled by 1 SD) and Month (categorical) on elephant Body Condition Score (mean score per Capture Event and the majority Age class for each Capture Event), in three time periods (1997 to 2018, 1997 to 2007 and 2008 to 2018). Models were fitted with a Gaussian error structure. Standard errors (SE), degrees of freedom (DF) and bootstrapped 95\% confidence intervals (CI; 1000 replicates) are also given. For the period 1997 to 2007, no data were available for the months of December and January (see Methods). The intercept is for the earliest month in a given time period, and for an Adult where Age is in the top model.

\begin{tabular}{lccccc}
\hline \multirow{2}{*}{ Variable } & Estimate & SE & DF & $-95 \%$ & $+95 \%$ \\
& & & CI & CI \\
\hline
\end{tabular}

1997 to 2018

$\begin{array}{lccccc}\text { Intercept } & 4.37 & 0.31 & 893 & 3.77 & 4.97 \\ \text { Month Feb } & 0.41 & 0.38 & 893 & -0.32 & 1.15 \\ \text { Month Mar } & 0.10 & 0.40 & 893 & 3.77 & 4.97 \\ \text { Month Apr } & -0.33 & 0.35 & 893 & -0.32 & 1.15 \\ \text { Month May } & -0.01 & 0.36 & 893 & 3.77 & 4.97 \\ \text { Month Jun } & -0.30 & 0.37 & 893 & -0.32 & 1.15 \\ \text { Month Jul } & 0.05 & 0.35 & 893 & 3.77 & 4.97 \\ \text { Month Aug } & -0.09 & 0.34 & 893 & -0.32 & 1.15 \\ \text { Month Sept } & 0.10 & 0.32 & 893 & 3.77 & 4.97 \\ \text { Month Oct } & 0.24 & 0.32 & 893 & -0.32 & 1.15 \\ \text { Month Nov } & 0.27 & 0.32 & 893 & 3.77 & 4.97 \\ \text { Month Dec } & 0.17 & 0.33 & 893 & -0.32 & 1.15\end{array}$

1997 to 2007

\begin{tabular}{lccccc} 
Intercept & 4.96 & 0.31 & 137 & 4.36 & 5.57 \\
Year & 0.17 & 0.07 & 137 & 0.02 & 0.31 \\
Month Mar & -0.72 & 0.54 & 137 & -1.77 & 0.33 \\
Month Apr & -0.86 & 0.33 & 137 & -1.51 & -0.21 \\
Month May & -0.44 & 0.39 & 137 & -1.21 & 0.32 \\
Month Jun & -0.72 & 0.41 & 137 & -1.52 & 0.08 \\
Month Jul & -0.50 & 0.34 & 137 & -1.18 & 0.18 \\
Month Aug & -0.14 & 0.46 & 137 & -1.05 & 0.77 \\
Month Sept & 0.16 & 0.35 & 137 & -0.52 & 0.85 \\
Month Oct & 0.69 & 0.50 & 137 & -0.29 & 1.68 \\
\hline
\end{tabular}




\begin{tabular}{lccccc}
\hline Variable & Estimate & SE & DF & $\begin{array}{c}\mathbf{- 9 5 \%} \\
\text { CI }\end{array}$ & $\begin{array}{c}\mathbf{+ 9 5 \%} \\
\text { CI }\end{array}$ \\
\hline Month Nov & -1.01 & 0.61 & 137 & -2.22 & 0.19
\end{tabular}

2008 to 2018

$\begin{array}{lccccc}\text { Intercept } & 4.51 & 0.32 & 744 & 3.88 & 5.14 \\ \text { Year } & -0.13 & 0.06 & 744 & -0.24 & -0.02 \\ \text { Month Feb } & 0.95 & 0.50 & 744 & -0.02 & 1.93 \\ \text { Month Mar } & 0.16 & 0.44 & 744 & -0.70 & 1.02 \\ \text { Month Apr } & -0.22 & 0.43 & 744 & -1.05 & 0.62 \\ \text { Month May } & -0.08 & 0.40 & 744 & -0.88 & 0.71 \\ \text { Month Jun } & -0.50 & 0.45 & 744 & -1.38 & 0.37 \\ \text { Month Jul } & 0.02 & 0.42 & 744 & -0.79 & 0.84 \\ \text { Month Aug } & -0.22 & 0.36 & 744 & -0.92 & 0.48 \\ \text { Month Sept } & -0.11 & 0.34 & 744 & -0.77 & 0.55 \\ \text { Month Oct } & 0.06 & 0.33 & 744 & -0.59 & 0.71 \\ \text { Month Nov } & 0.15 & 0.34 & 744 & -0.51 & 0.81 \\ \text { Month Dec } & 0.06 & 0.35 & 744 & -0.62 & 0.74\end{array}$




\section{References}

30. P. Albl, Studies on assessment of physical condition in African elephants. Biol. Conserv. 3, 134-140 (1971).

31. C. Wemmer, V. Krishnamurthy, S. Shrestha, L.-A. Hayek, M. Thant, K. A. Nanjappa, Assessment of body condition in Asian elephants (Elephas maximus). Zoo Biol. 25, 187200 (2006).

32. P. Fernando, H. K. Janaka, S. K. K. Ekanayaka, H. G. Nishantha, J. Pastorini, A Simple Method for Assessing Elephant Body Condition. Gajah, 31 29-31 (2009).

33. K. A. Morfeld, C. L. Meehan, J. N. Hogan, J. L. Brown, Assessment of body condition in African (Loxodonta africana) and Asian (Elephas maximus) elephants in North American zoos and management practices associated with high body condition scores. PLoS One. 11 e0155146 (2016).

34. C. Schiffmann, et al., Body condition scores in European zoo elephants (Elephas maximus and Loxodonta africana): status quo and influencing factors. J. Zoo Aquarium Res. 6, 91103 (2018).

35. K. A. Morfeld, J. Lehnhardt, C. Alligood, J. Bolling, J. L. Brown, Development of a body condition scoring index for female African elephants validated by ultrasound measurements of subcutaneous fat. PLoS One. 9 e0093802 (2014).

36. C. Schiffmann, M. Clauss, S. Hoby, J.-M. Hatt, Visual body condition scoring in zoo animals - composite, algorithm and overview approaches. J. Zoo Aquarium Res. 5, 1-10 (2017).

37. W. Chang, J. Cheng, J. Allaire, Y. Xie, J. McPherson, shiny: Web Application Framework for R (2020).

38. W. Revelle, psych: Procedures for Psychological, Psychometric, and Personality Research. R package version 1.9.12 (2018).

39. D. Bates, M. Mächler, B. M. Bolker, S. C. Walker, Fitting linear mixed-effects models using lme4. J. Stat. Softw. 67 jss.v067.i01 (2015).

40. R Core. Team, R: A language and environment for statistical computing. (2020).

41. A. F. Zuur, E. N. Ieno, R. Freckleton, A protocol for conducting and presenting results of regression-type analyses. Methods Ecol. Evol. 7, 636-645 (2016).

42. V. Obanda, T. Iwaki, N. M. Mutinda, F. Gakuya, Gastrointestinal Parasites and Associated Pathological Lesions in Starving Free-Ranging African Elephants. South African J. Wildl. Res. 41, 167-172 (2011).

43. Y. A. Wato, I. M. A. Heitkönig, S. E. van Wieren, G. Wahungu, H. H. T. Prins, F. van Langevelde, Prolonged drought results in starvation of African elephant (Loxodonta 
africana). Biol. Conserv. 203, 89-96 (2016).

44. E. J. Bergman, P. F. Doherty, C. J. Bishop, L. L. Wolfe, B. A. Banulis, Herbivore Body Condition Response in Altered Environments: Mule Deer and Habitat Management. PLoS One. 9, e106374 (2014).

45. S. S. Pokharel, P. B. Seshagiri, R. Sukumar, Assessment of season-dependent body condition scores in relation to faecal glucocorticoid metabolites in free-ranging Asian elephants. Conserv. Physiol. 5 cox039 (2017).

46. A. M. Allen, A. Dorey, J. Malmsten, L. Edenius, G. Ericsson, N. J. Singh, Habitatperformance relationships of a large mammal on a predator-free island dominated by humans. Ecol. Evol. 7, 305-319 (2017).

47. A. Cuni-Sanchez, et al., African savanna-forest boundary dynamics: A 20-year study. PLoS One. 11, e0156934 (2016).

48. M. Johnson-Bawe, thesis, Cardiff University (2008).

49. S. G. Schuttler, J. A. Philbrick, K. J. Jeffery, L. S. Eggert, Fine-Scale Genetic Structure and Cryptic Associations Reveal Evidence of Kin-Based Sociality in the African Forest Elephant. PLoS One. 9, e88074 (2014).

50. C. A. Sánchez, et al., On the relationship between body condition and parasite infection in wildlife: a review and meta-analysis. Ecol. Lett. 21, 1869-1884 (2018).

51. R. K. Davidson, T. Ličina, L. Gorini, J. M. Milner, Endoparasites in a Norwegian moose (Alces alces) population - Faunal diversity, abundance and body condition. Int. J. Parasitol. Parasites Wildl. 4, 29-36 (2015).

52. F. Jiang, et al., Assessing the impact of climate change on the spatio-temporal distribution of foot-and-mouth disease risk for elephants. Glob. Ecol. Conserv. 23, e01176 (2020).

53. K. D. Rode, P. I. Chiyo, C. A. Chapman, L. R. McDowell, Nutritional ecology of elephants in Kibale National Park, Uganda, and its relationship with crop-raiding behaviour. J. Trop. Ecol. 22, 441-449 (2006).

54. L Bahaa-el-din, et al., Notes on the distribution and status of small carnivores in Gabon. Small Carniv. Conserv. 48, 19-29 (2013). 